\title{
Delivery of natural phenolic compounds for the potential treatment of lung cancer
}

\author{
Ashley G. Muller ${ }^{1}$ (D) - Satyajit D. Sarker ${ }^{1} \cdot$ Imran Y. Saleem $^{1} \cdot$ Gillian A. Hutcheon $^{1}$ \\ Received: 17 October 2018 / Accepted: 17 April 2019 / Published online: 21 May 2019 \\ (C) The Author(s) 2019
}

\begin{abstract}
The application of natural products to treat various diseases, such as cancer, has been an important area of research for many years. Several phytochemicals have demonstrated anticarcinogenic activity to prevent or reduce the progression of cancer by modulating various cellular mechanisms. However, poor bioavailability has hindered clinical success and the incorporation of these drugs into efficient drug delivery systems would be beneficial. For lung cancer, local delivery via the pulmonary route would also be more effective. In this article, recent in vitro scientific literature on phenolic compounds with anticancer activity towards lung cancer cell lines is reviewed and nanoparticulate delivery is mentioned as a possible solution to the problem of bioavailability. The first part of the review will explore the different classes of natural phenolic compounds and discuss recent reports on their activity on lung cancer cells. Then, the problem of the poor bioavailability of phenolic compounds will be explored, followed by a summary of recent advances in improving the efficacy of these phenolic compounds using nanoparticulate drug delivery systems.
\end{abstract}

Keywords Phenolic compound $\cdot$ Lung cancer $\cdot$ Drug delivery $\cdot$ Polymeric nanoparticle $\cdot$ Pulmonary delivery

$\begin{array}{ll}\begin{array}{l}\text { Abbreviations } \\ \text { 4-ACGC }\end{array} & \begin{array}{l}\text { 4-O-(2"-O-acetyl-6"-O-p-coumaroyl- } \beta \text {-d- } \\ \text { glucopyranosyl)-p-coumaric acid }\end{array} \\ \text { 5HHMF } & \text { 5-hydroxy-3,6,7,8,3',4'-hexamethoxyflavone } \\ \text { 5HPMF } & \text { 5-hydroxy-3,7,8,3',4'-pentamethoxyflavone } \\ \text { AP-1 } & \text { activator protein-1 } \\ \text { AIF } & \text { apoptosis-inducing factor } \\ \text { ARRB2 } & \text { arrestin beta } 2 \\ \text { Bcl-2 } & \text { B cell lymphoma 2 } \\ \text { Bad } & \text { Bcl-2-associated death promoter } \\ \text { Bax } & \text { Bcl-2-associated X protein } \\ \text { JNK } & \text { c-Jun N-terminal kinases } \\ \text { COX-2 } & \text { cyclooxygenase } \\ \text { POLL } & \text { DNA polymerase lambda } \\ \text { H69VP } & \text { drug-resistant small-cell lung carcinoma } \\ \text { H69 } & \text { drug-sensitive small-cell lung carcinoma }\end{array}$

Ashley G. Muller

ashleygeorgemuller@gmail.com

School of Pharmacy \& Biomolecular Sciences, Liverpool John Moores University, James Parsons Building, 3 Byrom Street, Liverpool L3 3AF, UK

\begin{tabular}{|c|c|}
\hline DPIs & dry powder inhalers \\
\hline ER & endoplasmic reticulum \\
\hline EGFR & epidermal growth factor receptor \\
\hline EGFR-TKIs & $\begin{array}{l}\text { epidermal growth factor receptor tyrosine } \\
\text { kinase inhibitors }\end{array}$ \\
\hline EGCG & Epigallocatechin 3-gallate \\
\hline EMT & Epithelial-Mesenchymal Transition \\
\hline ERK $1 / 2$ & extracellular signal-regulated kinase 1 and 2 \\
\hline GRP78 & glucose-regulated protein 78 \\
\hline GADD 153 & $\begin{array}{l}\text { growth arrest- and DNA damage-inducible } \\
\text { gene } 153\end{array}$ \\
\hline GADD 45 & $\begin{array}{l}\text { growth arrest- and DNA damage-inducible } \\
\text { gene } 45\end{array}$ \\
\hline A549 & human lung adenocarcinoma cell line \\
\hline SPC-A-1 & human lung cancer cell line \\
\hline NSCLC & human non-small cell lung cancer \\
\hline iNOS & inducible nitric oxide \\
\hline IC50 & inhibitory concentration $50 \%$ \\
\hline mTOR & mammalian target of rapamycin \\
\hline MMP-9 & matrix metalloproteinase- 9 \\
\hline MMP-2 & matrix metalloproteinase- 2 \\
\hline miRNA & microRNA \\
\hline MAPK1 & mitogen-activated protein kinase 1 \\
\hline
\end{tabular}




\begin{tabular}{|c|c|}
\hline MAPK14 & mitogen-activated protein kinase 14 \\
\hline MEK & mitogen-activated protein kinase and ERK \\
\hline MAPK3/6 & mitogen-activated protein kinase kinases $3 / 6$ \\
\hline MAPK & mitogen-activated protein kinases \\
\hline MLK3 & mixed lineage protein kinase 3 \\
\hline MDM2 & mouse double minute 2 \\
\hline MAP & mucoadhesive particles \\
\hline MPP & mucus-penetrating particles \\
\hline MUTYH & MutY DNA Glycosylase \\
\hline Mcl-1 & myeloid cell leukemia-1 \\
\hline NAR/CS NPs & $\begin{array}{l}\text { naringenin encapsulated chitosan } \\
\text { nanoparticles }\end{array}$ \\
\hline $\begin{array}{l}\mathrm{H} 2122, \mathrm{H} 358, \\
\mathrm{H} 460, \mathrm{H} 1650, \\
\mathrm{H} 1975 \text {, and } \\
\mathrm{H} 1993\end{array}$ & NSCLC cell lines \\
\hline NFKB1 & nuclear factor kappa $b$ subunit 1 \\
\hline NF-kB & $\begin{array}{l}\text { nuclear factor kappa-light-chain-enhancer } \\
\text { of activated B cells }\end{array}$ \\
\hline P-OA-CTS & $\begin{array}{l}\text { paclitaxel- oleic acid-conjugated chitosan } \\
\text { nanoparticles }\end{array}$ \\
\hline $\mathrm{PI} 3 \mathrm{~K} / \mathrm{Akt}$ & phosphoinositide 3-Kinase/protein kinase B \\
\hline PLGA & poly (lactic-co-glycolic acid) \\
\hline PARP & poly(ADP-ribose) polymerase \\
\hline PEG & poly(ethylene glycol) \\
\hline PVA & poly(vinyl alcohol) \\
\hline PVP & polyvinylpyrrolidone \\
\hline PCL & polycaprolactone \\
\hline PLA & polylactic acid \\
\hline PCNA & proliferating cell nuclear antigen \\
\hline PGE2 & prostaglandin E2 \\
\hline PTK2 & protein tyrosine kinase 2 \\
\hline Q-OA-CTS & $\begin{array}{l}\text { quercetin-oleic acid-conjugated chitosan } \\
\text { nanoparticles }\end{array}$ \\
\hline ROS & reactive oxygen species \\
\hline RTK & receptor tyrosine kinases \\
\hline R-GNPs & $\begin{array}{l}\text { resveratrol encapsulated gelatin } \\
\text { nanoparticles }\end{array}$ \\
\hline STAT5A & $\begin{array}{l}\text { signal transducer and activator of transcrip- } \\
\text { tion } 5 \mathrm{a}\end{array}$ \\
\hline STAT3 & $\begin{array}{l}\text { signal transducer and activator of transcrip- } \\
\text { tion protein } 3\end{array}$ \\
\hline STATs & $\begin{array}{l}\text { signal transducer and activator of transcrip- } \\
\text { tion proteins }\end{array}$ \\
\hline SCLC & small-cell lung carcinoma \\
\hline TGF- $\beta 1$ & transforming growth factor beta 1 \\
\hline TSA & trichostatin A \\
\hline TNF & tumour necrosis factor \\
\hline TNFR-1 & tumour necrosis factor receptor-1 \\
\hline TP53 & Tumour protein $\mathrm{p} 53$ \\
\hline TAM & Tyro3, Axl, MerTK \\
\hline TKI & tyrosine kinase inhibitors \\
\hline $\mathrm{u}-\mathrm{PA}$ & urokinase-type plasminogen activator \\
\hline
\end{tabular}

FDA US Food and Drug Administration

VEGF Vascular Endothelial Growth Factor

VEGFA vascular endothelial growth factor A

\section{Introduction}

According to Cancer research UK, lung cancer is the third most common cancer in the UK with around 46,700 new cases reported each year, accounting for $21 \%$ of all cancer deaths and it has the second lowest ten-year survival rate $(5 \%)$ of all cancers [1] . This is despite the fact that $89 \%$ of all lung cancers are linked to lifestyle or environmental risk factors and hence preventable [1]. Cancer chemoprevention consist of the chronic use of a synthetic, natural or biological agent to reduce or inhibit the formation and progression of cancer, in which oxidative stress is a key factor [2]. Plants and fungi produce secondary metabolites, such as phenolic compounds, as a protective measure against oxidative stress caused by ultraviolet light, insects, viruses, and bacteria [3]. Therefore, it is postulated that these same metabolites could be applied to help protect humans from diseases, such as cancer, caused by oxidative stress. A review on the link of oxidative stress in cancer is beyond the scope of this review, but can be found in several sources $[4,5]$. It should be noted that current literature is divided as to whether or not phenolic compounds used in conjunction with chemotherapy and/or radiation therapy reduces the efficacy of cancer treatment [6-8]. It is the intention that the phenolic compounds discussed in this review be considered for use as a treatment for lung cancer, in and of itself, and not to be used in conjunction with current cancer chemotherapy and/ or radiation treatment. Several different techniques are used to extract, separate, and identify phenolic compounds from natural sources in a pure form required for clinical use, including liquidliquid extraction, solid-liquid extraction, supercritical fluid extraction, high performance liquid chromatography, supercritical fluid chromatography, mass spectrometry, nuclear magnetic resonance spectroscopy, amongst others $[9,10]$.

A previous systematic review discovered that eating fruits and vegetables can confer up to an $18 \%$ decrease in the risk of developing lung cancer [11]. It is hypothesised that the reason behind the decreased lung cancer risk is due to the high amounts of flavonoids, and other phenolic compounds, present in the fruits and vegetables $[12,13]$.

The following section will list and describe the categories of the different phenolic compounds and examples of them that have been shown to have anticancer properties.

\section{Phenolic compounds}

Phenolic compounds are diverse in structure, but are identified as having at least one aromatic ring possessing one or more 
hydroxyl groups [14]. Several classes of phenolic compounds exist, namely, flavonoids, phenolic acids, phenolic alcohols, stilbenes and lignans $[10,15]$. Phenolic compounds are ubiquitous, being present in almost all of the foods we consume, from plant derived foods, including fruits, vegetables, legumes and cereals to beverages such as beer, coffee, tea, wine and also in spices and herbs, such as cinnamon, curcumin, sage, and thyme [16-19].

\section{Flavonoids}

Flavonoids, the largest and most widely studied class of phenolic compounds, can be subdivided into flavonols, flavones, flavanones, isoflavones, anthocyanidins, and catechins [10]. Tannins are flavonoids that, as a result of the plants themselves or from food processing, are polymerised into large molecules [20]. There are two types of tannins, namely hydrolysable tannins and condensed tannins. Hydrolysable tannins (which contain glucose or another polyol as their central core) are subclassed as gallotannins (core esterification by gallic acid) or ellagitannins (core esterification by hexahydroxydiphenic acid) [21]. Condensed tannins are also known as proanthocyanidins and are polymeric or oligomeric compounds made from flavan-3-ol [21]. The chemical structures of the main classes of flavonoids and the examples listed below are presented in Figs. 1 and 2, respectively. Refer to Table 1 for the list of studies discussed below.

Epigallocatechin 3-gallate (EGCG) is the most abundant catechin (flavonoid) present in both black- and green tea (Camellia sinensis) (refer to Fig. 2 for structure). It has been shown to have several actions, inter alia, anti-oxidative [22], anti-inflammatory [23], anticancer [24], promotion of cell cycle arrest [25], inhibition of cellular proliferation [26], proapoptotic [27], antimetastatic and anti-angiogenic [28]. The antitumour activity of EGCG is postulated to be due to its interaction with several signalling pathways. The pathways include protein kinase suppression, inhibition of transcription factors such as nuclear factor kappa-light-chain-enhancer of activated B cells (NF-kB), epidermal growth factor receptor (EGFR), activator protein-1 (AP1) and signal transducer and activator of transcription proteins (STATs), and mechanisms such as induction of apoptosis or cell cycle arrest and prevention of metastasis [29-32]. A study by Jin et al. [29] found that treating three human lung cancer cell lines (A549, H1650 and H460) with $20 \mu \mathrm{M}$ EGCG inhibited anchorage-independent growth of all three cell lines via upregulation of $\mathrm{p} 53$ expression, increased phosphorylation of tumour protein p53 (TP53) at anti-phospho-p53 $\left(\mathrm{Ser}^{15}\right)$ and antiphospho-p53 $\left(\mathrm{Ser}^{20}\right)$ and enhancement of its transcriptional activity, as well as inhibition of mouse double minute 2 (MDM2)mediated TP53 ubiquitination. Another study found that treatment of EGCG $(5-50 \mu \mathrm{M})$ resulted in increased expression of miR-210, leading to growth inhibition of human non-small cell lung cancer cell lines, H1299 and H460 [30]. The effect of<smiles>CC1=C(c2ccccc2)Cc2ccccc2C1=O</smiles>

FLAVONOL<smiles>O=C1CC(c2ccccc2)Oc2ccccc21</smiles>
FLAVANONE<smiles>Oc1cc(O)c2c(c1)O[C@H](c1ccc(O)c(O)c1)[C@H](O)C2</smiles>

FLAVANOL (CATECHINS)<smiles>O=c1cc(-c2ccccc2)oc2ccccc12</smiles>

FLAVONE<smiles>O=c1c(-c2ccccc2)coc2ccccc12</smiles>
ISOFLAVONE<smiles></smiles>

ANTHOCYANIDINE
Fig. 1 Chemical structure of flavonoids

EGCG on drug-sensitive (H69) and drug-resistant (H69VP) small-cell lung carcinoma (SCLC) cells was studied. It was found that exposure of both cell lines to $70 \mu \mathrm{M}$ EGCG for $24 \mathrm{~h}$ resulted in a 50-60\% reduction in telomerase activity with initiation of apoptosis through decreased activity of caspases-3 and -9, DNA fragmentation in cells, and cell-cycle arrest [31]. A similar study assessed the effect of EGCG on various human non-small cell lung cancer (NSCLC) cell lines (H2122, H358, H460, H1975, and H1993) that were either erlotinib-sensitive, erlotinib-resistant, showed c-Met overexpression and/or had acquired erlotinib resistance. Exposure of the cell lines to 2.5$40 \mu \mathrm{mol} / \mathrm{L}$ of EGCG resulted in a dose-dependent inhibition of cell proliferation [32]. EGCG co-administered with the antilung cancer drug, leptomycin, showed a synergistic increase in cytotoxicity of the human lung cancer A549 cells [33].

Two flavonoids, 5 -hydroxy-3, $7,8,3^{\prime}, 4^{\prime}$ pentamethoxyflavone (5HPMF), and 5-hydroxy-3,6,7,8, '3', $4^{\prime}$ hexamethoxyflavone (5HHMF), are found in sweet orange (Citrus sinensis) (refer to Fig. 2 for structures). These two flavonoids were shown to initiate apoptosis through activation of caspase-3 and cleavage of poly(ADP-ribose) polymerase (PARP) (a substrate of activated caspase-3) as well as downregulating oncogenic proteins, such as inducible nitric oxide (iNOS), cyclooxygenase (COX-2), myeloid cell leukemia-1 (Mcl-1), and K-ras in human lung carcinoma H1299 cells [34]. The inhibitory concentration $\left(\mathrm{IC}_{50}\right)$ values for the two flavonoids after $24 \mathrm{~h}$ was recorded as $16.5 \mu \mathrm{M}$.

Genistein, also known as 5,7-dihydroxy-3-(4hydroxyphenyl)-4H-1-benzopyran-4-one and 4',5,7- 
<smiles>O=C(O[C@H]1Cc2c(O)cc(O)cc2O[C@H]1c1cc(O)c(O)c(O)c1)c1cc(O)c(O)c(O)c1</smiles>

EPIGALLOCATECHIN GALLATE (EGCG)<smiles>O=c1c(O)c(-c2ccc(O)c(O)c2)oc2cc(O)ccc12</smiles><smiles>O=c1cc(-c2ccc(O)c(O)c2)oc2cc(O)cc(O)c12</smiles>

LUTEOLIN<smiles>O=C1c2c(O)cc(O)cc2OCC1c1ccc(O)cc1</smiles>

GENISTEIN<smiles>O=C(CCc1ccc(O)cc1)c1c(O)cc(O)cc1O</smiles>

PHLORETIN

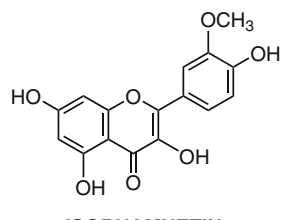

ISORHAMNETIN<smiles>COC1=C(O)C(O)=C(O)C2C(=O)C=C(c3ccc(OC)c(OC)c3)OC12</smiles>

5-HYDROXYPENTAMETHOXYFLAVONE (5HPMF)<smiles></smiles>

QUERCETIN<smiles>COC1=C(c2ccc(OC)c(OC)c2)OC2C(OC)=C(O)C(OC)=C(O)C2C1=O</smiles>

5-HYDROXYHEXAMETHOXYFLAVONE (5HHMF)<smiles>O=c1c(O)c(-c2ccc(O)cc2)oc2cc(O)cc(O)c12</smiles>

KAEMPFEROL

Fig. 2 Chemical structures of flavonoids listed in paper

trihydroxyisoflavone, is the most abundant isoflavone found in soybean (Glycine max) (refer to Fig. 2 for structure). Shiau et al. [35] exposed A549 cells to a combination of $10 \mu \mathrm{M}$ genistein and $50 \mathrm{ng} / \mathrm{mL}$ of trichostatin A (TSA), resulting in enhanced inhibition of growth and increased apoptosis, thought partly to be due to increased caspase-3 activity. A subsequent study revealed that the same combination augmented the anticancer effect of TSA by increasing tumour necrosis factor (TNF) receptor-1 (TNFR-1) death receptor signalling [36]. Gadgeel et al. [37] studied the effect of genistein in combination with epidermal growth factor receptor tyrosine kinase inhibitors (EGFR-TKIs), erlotinib and gefitinib on NSCLC cell lines with various EGFR mutations and sensitivities to EGFR-TKIs, H3255, H1650, and H1781 (wild-type EGFR). Genistein $(25 \mu \mathrm{M})$ in combination with erlotinib/ gefitinib increased the growth inhibition and apoptosis in all three cell lines postulated to be due to decreased DNA-binding activity of NF- $\mathrm{kB}$ and a reduction in COX-2, pAkt, EGFR and prostaglandin E2 $\left(\mathrm{PGE}_{2}\right)$ expression [37]. Exposure of the human lung adenocarcinoma SPC-A-1 cell line to 20 $40 \mu \mathrm{M}$ genistein resulted in cell-cycle arrest, antiproliferation and induction of apoptosis via regulation of genes related to apoptosis, especially genes from the B cell lymphoma 2 (Bcl2) family and TNF ligand and receptor family [38]. Treatment of H460 cells with $15-30 \mu \mathrm{mol} / \mathrm{L}$ genistein combined with cisplatin, docetaxel or doxorubicin resulted in a greater synergistic effect cell-growth inhibition and induction of apoptosis than compared with either one by itself [39]. It was found that the pre-exposure of the cells to the genistein inactivated NF-KB thereby nullifying the NF-KB-inducing activity of cisplatin, docetaxel and doxorubicin [39].
The flavonoid, fisetin $\left(3,7,3^{\prime}, 4^{\prime}\right.$-tetrahydroxyflavone) is naturally found in several foods including grape, persimmon, strawberry apple, onion, and cucumber [40] (refer to Fig. 2 for structure). Khan et al. [41] exposed A549 cells to 5$20 \mu \mathrm{M}$ fisetin causing a dose-dependent inhibition of both phosphoinositide 3-Kinase/protein kinase B (PI3K/Akt) and mammalian target of rapamycin (mTOR) signaling through attenuating PI3K protein expression, inhibiting Akt and mTOR phosphorylation. Fisetin $(1,5$ and $10 \mu \mathrm{M})$ was shown to inhibit the ability of A549 cells to adhere, migrate, and invade, by interfering with the regulation of extracellular signal-regulated kinase 1 and 2 (ERK1/2), matrix metalloproteinase-2 (MMP2), and urokinase-type plasminogen activator (u-PA) at both the protein and microRNA (miRNA) levels [42]. There was also a concentration-dependent inhibitory effect on NF-KB and AP-1 binding with a significant decrease in the nuclear levels of NF-KB, c-Fos, and c-Jun [42].

Phloretin, 3-(4-hydroxyphenyl)-1-(2,4,5trihydroxyphenyl), is a flavonoid from several sources including apples and plants, such as Hoveniae Lignum, Pieris japonica, and Loiseleuria procumbens [43] (refer to Fig. 2 for structure). It was found that administration of $125-150 \mu \mathrm{g} /$ $\mathrm{mL}$ of phloretin to NSCLC cell lines A549, Calu-1, H838 and $\mathrm{H} 520$ caused a dose-dependent decrease in proliferation and induction of apoptosis through suppressing the expression of Bcl-2, increasing cleaved-caspase-3 and -9 protein expression, and downregulating MMP-2 and -9 expression on gene and protein levels [43]. Min et al. [44] showed that phloretin $(25,50,100$ and $200 \mu \mathrm{M})$ caused a dose- and time-dependent inhibition of migration and an increase in apoptosis of A549 cells through upregulating ERK, c-Jun N-terminal kinases 
Table 1 List of flavonoids with potential anticancer activity against various lung cancer cell lines

\begin{tabular}{|c|c|c|c|c|}
\hline Flavonoid & Concentration & Cell line & Mechanisms & Reference \\
\hline \multirow[t]{4}{*}{ EGCG } & $20 \mu \mathrm{M}$ & A549 H1650 H460 & Upregulation of TP53 causing growth inhibition & [29] \\
\hline & $5-50 \mu \mathrm{M}$ & H1299 H460 & Increased expression of miR-210, leading to growth inhibition & {$[30]$} \\
\hline & $70 \mu \mathrm{M}$ & $\begin{array}{l}\text { H69 } \\
\text { H69VP }\end{array}$ & $\begin{array}{l}\text { Reduced tolomerase activity, apoptosis induction, DNA fragmentation, } \\
\text { and cell cycle arrest }\end{array}$ & {$[31]$} \\
\hline & $2.5-40 \mu \mathrm{mol} / \mathrm{L}$ & $\begin{array}{l}\text { H2122 H358 H460 } \\
\text { H1975 H1993 }\end{array}$ & Inhibition of cell proliferation & {$[32]$} \\
\hline 5HPMF & $16.5 \mu \mathrm{M}$ & H1299 & Apoptosis through activation of caspase- 3 & {$[34]$} \\
\hline 5HHMF & $16.5 \mu \mathrm{M}$ & H1299 & Apoptosis through activation of caspase-3 & [34] \\
\hline \multirow[t]{4}{*}{ Genistein } & $\begin{array}{l}10 \mu \mathrm{M}+50 \mathrm{ng} / \mathrm{mL} \\
\text { trichostatin } \mathrm{A}\end{array}$ & A549 & $\begin{array}{l}\text { Enhanced inhibition of growth and increased apoptosis by increasing } \\
\text { TNFR-1 death receptor signalling }\end{array}$ & {$[35]$} \\
\hline & $25 \mu \mathrm{M}$ & H3255 H1650 H1781 & $\begin{array}{l}\text { Decreased DNA-binding activity of NF- } \mathrm{KB} \text { and a reduction in COX-2, } \\
\text { pAkt, EGFR and } \mathrm{PGE}_{2} \text { expression }\end{array}$ & {$[37]$} \\
\hline & $20-40 \mu \mathrm{M}$ & SPC-A-1 & $\begin{array}{l}\text { Cell-cycle arrest, antiproliferation, induction of apoptosis via regulation } \\
\text { of genes related to apoptosis }\end{array}$ & {$[38]$} \\
\hline & $15-30 \mu \mathrm{mol} / \mathrm{L}$ & $\mathrm{H} 460$ & $\begin{array}{l}\text { Nullified the NF-kB-inducing activity of cisplatin, docetaxel and } \\
\text { doxorubicin increasing cell-growth inhibition and inducing of apoptosis }\end{array}$ & {$[39]$} \\
\hline \multirow[t]{2}{*}{ Fisetin } & $5-20 \mu \mathrm{M}$ & A549 & $\begin{array}{l}\text { Inhibition of both PI3K/Akt and mTOR signalling through attenuating } \\
\text { PI3K protein expression, inhibiting Akt and mTOR phosphorylation }\end{array}$ & {$[41]$} \\
\hline & $1,5,10 \mu \mathrm{M}$ & A549 & $\begin{array}{l}\text { Downregulation of ERK1/2, MMP-2, and u-PA. Inhibition of NF- } \mathrm{B} \\
\text { and AP-1 binding. Decrease in the nuclear levels of NF- } \mathrm{B} \text {, c-Fos, } \\
\text { and c-Jun }\end{array}$ & {$[42]$} \\
\hline \multirow[t]{2}{*}{ Phloretin } & $125-150 \mu \mathrm{g} / \mathrm{mL}$ & $\begin{array}{l}\text { A549 Calu-1 } \\
\text { H838 H520 }\end{array}$ & $\begin{array}{l}\text { Decreased proliferation, induction of apoptosis, Bcl-2 expression } \\
\text { suppression, increased cleaved-caspase- } 3 \text { and }-9 \text { protein expression, } \\
\text { MMP-2 and }-9 \text { downregulation }\end{array}$ & {$[43]$} \\
\hline & $\begin{array}{l}25,50,100 \text { and } \\
200 \mu \mathrm{M}\end{array}$ & A549 & $\begin{array}{l}\text { Inhibit migration, increase apoptosis via upregulating ERK, JNK, Bax } \\
\text { and P38 MAPK and activating caspase-3 and -9, and TP53 while } \\
\text { downregulating Bcl-2 and NF-KB }\end{array}$ & {$[44]$} \\
\hline Quercetin & $0.74-4.40 \mu \mathrm{mol} / \mathrm{L}$ & A549 & Dose-dependent decrease in cell growth and an increase in apoptosis & [45] \\
\hline \multirow[t]{3}{*}{ Kaempferol } & $10-140 \mu \mathrm{M}$ & A549 & $\begin{array}{l}\text { Dose-dependent antiproliferative activity and impaired metastasis via } \\
\text { suppression of EMT }\end{array}$ & {$[56]$} \\
\hline & $25 \mu \mathrm{M}$ & A549 & $\begin{array}{l}\text { EMT suppression induced by inhibiting the phosphorylation of Smad3 at } \\
\text { Threonine- } 179 \text { by Akt1 }\end{array}$ & {$[57]$} \\
\hline & 30,50 and $80 \mu \mathrm{M}$ & H460 & Apoptosis via induction caspase- 3 , AIF, and increasing antioxidant enzymes & {$[58]$} \\
\hline \multirow[t]{5}{*}{ Luteolin } & $20-80 \mu \mathrm{M}$ & A549 & $\begin{array}{l}\text { Cell cycle arrest and inducing apoptosis through activating JNK, increasing } \\
\text { Bax, promoting procaspase- } 9 \text { cleavage, and activating caspase-3 }\end{array}$ & {$[51]$} \\
\hline & $25-100 \mu \mathrm{M}$ & A549 & $\begin{array}{l}\text { Apoptotic effect and reduction of cell motility and cell migration. } \\
\text { Upregulation of caspase- } 3 \text { and caspase-9, downregulation of Bcl-2, } \\
\text { increase in expression of Bax, phosphorylation of mitogen-activated } \\
\text { protein kinase and extracellular regulated protein kinase (MEK), and } \\
\text { activation of Akt }\end{array}$ & {$[52]$} \\
\hline & $10-100 \mu \mathrm{M}$ & $\begin{array}{l}\text { A5 } 599 \\
\text { H460 }\end{array}$ & $\begin{array}{l}\text { Inhibition of cell proliferation and increased apoptosis via upregulation of } \\
\text { a microRNA (miR-34a-5p) that targets an oncogene (MDM4) }\end{array}$ & {$[53]$} \\
\hline & $20-80 \mu \mathrm{M}$ & $\begin{array}{l}\text { A5 } 59 \\
\text { H460 }\end{array}$ & $\begin{array}{l}\text { Decrease in cell proliferation by downregulation of the Tyro3, Axl, MerTK } \\
\text { (TAM) receptor tyrosine kinases (RTK) }\end{array}$ & {$[54]$} \\
\hline & $20-160 \mu \mathrm{M}$ & $\mathrm{H} 460$ & Antiproliferative effects via Sirt1-mediated apoptosis & {$[55]$} \\
\hline \multirow[t]{2}{*}{ Isorhamnetin } & $16 \mu \mathrm{M}$ & A549 & $\begin{array}{l}\text { Inhibition of cellular proliferation and colony formation and an increase in } \\
\text { apoptosis via the mitochondria-dependent pathway with caspase activation }\end{array}$ & {$[47]$} \\
\hline & $25 \mu \mathrm{M}$ & A549 & $\begin{array}{l}\text { Synergistically increase the antiproliferative and proapoptotic effects of the } \\
\text { anticancer drugs via disruption of the mitochondrial membrane potential } \\
\text { and activation of caspases and PARP }\end{array}$ & [48] \\
\hline \multirow[t]{2}{*}{ Hesperidin } & $5-50 \mu \mathrm{M}$ & A549 NCIH358 & $\begin{array}{l}\text { Inhibition of proliferation and induction of apoptosis via loss of } \\
\text { mitochondrial membrane potential, activation of caspase- } 3 \text {, and affecting } \\
\text { the fibroblast growth factor and NF- } \mathrm{KB} \text { signal transduction pathways }\end{array}$ & {$[60]$} \\
\hline & $5-100 \mu \mathrm{M}$ & H1993 & Suppression of cell viability & [61] \\
\hline Acacetin & $1-30 \mu \mathrm{M}$ & A549 & $\begin{array}{l}\text { Inhibition of cell viability, invasion and migration via disruption of several } \\
\text { signalling pathways and kinases including AP-1, NF-kB, c-Fos, c-Jun, } \\
\text { MLK3, MAPK3/6, and p38a MAPK }\end{array}$ & [62] \\
\hline
\end{tabular}


(JNK), Bcl-2-associated X protein (Bax) and P38 mitogenactivated protein kinases (MAPK) and activating caspase-3 and -9 , and TP53 while downregulating Bcl-2 and NF-KB.

Quercetin (3,3',4',5,7-pentahydroxyflavone) is the most common flavonol distributed in various plants and plant foods (refer to Fig. 2 for structure). Zheng et al. [45] studied the effect of quercetin $(0.74-4.40 \mu \mathrm{mol} / \mathrm{L})$ administration on A549 cells. It was found that quercetin caused a dose-dependent decrease in cell growth and an increase in apoptosis.

Isorhamnetin is a flavonoid that is an immediate metabolite of quercetin in mammals [46] (refer to Fig. 2 for structure). Ruan, Hu and Chen [47] showed that administration of $16 \mu \mathrm{M}$ isorhamnetin to A549 cells resulted in inhibition of cellular proliferation and colony formation and an increase in apoptosis via the mitochondria-dependent pathway with caspase activation. Isorhamnetin $(25 \mu \mathrm{M})$ when combined with $0.5 \mu \mathrm{M}$ each of cisplatin and carboplatin, synergistically increased the antiproliferative and proapoptotic effects of these anticancer drugs in A549 cells via disruption of the mitochondrial membrane potential and activation of caspases and PARP [48].

Luteolin, 3',4',5,7-tetrahydroxyflavone, is a flavone found naturally in its glycosylated form in various green vegetables including artichoke, broccoli, cabbage, celery, cauliflower, green pepper, and spinach $[49,50]$ (refer to Fig. 2 for structure). Administration of $20-80 \mu \mathrm{M}$ luteolin to A549 lung cancer cells caused a dose- and time-dependent cytotoxic effect by causing cell cycle arrest and inducing apoptosis through activating JNK, increasing Bax, promoting procaspase-9 cleavage, and activating caspase-3 [51]. Meng et al. [52] showed that luteolin $(25-100 \mu \mathrm{M})$ had a dose- and time-dependent antiproliferative and apoptotic effect on A549 lung cancer cells, also significantly reducing cell motility and cell migration. Luteolin was shown to upregulate caspase-3 and caspase-9, downregulate $\mathrm{Bcl}-2$, increase expression of bax, phosphorylate mitogenactivated protein kinase and ERK (MEK), and activate Akt [52]. Jiang et al. [53] caused a dose- and time-dependent inhibition of cell proliferation and increased apoptosis when administering luteolin $(10-100 \mu \mathrm{M})$ to human lung cancer A549 and H460 cells. The mechanism of action was found to be the upregulation of a microRNA (miR-34a-5p) that targets an oncogene (MDM4) [53]. Luteolin $(20-80 \mu \mathrm{M})$ caused a decrease in cell proliferation by downregulation of Tyro3, Axl, MerTK (TAM) receptor tyrosine kinases (RTK) in parental and cisplatin-resistant human lung cancer A549 and H460 cells [54]. Ma et al. [55] showed that luteolin $(20-160 \mu \mathrm{M})$ caused antiproliferative effects in human lung cancer NCI-H460 cells through Sirt1-mediated apoptosis.

Kaempferol (3, 4',5,7-tetrahydroxyflavone) is another common dietary flavonoid (refer to Fig. 2 for structure). Hang et al. [56] administered 10-140 $\mu \mathrm{M}$ kaempferol to A549 cells and show that it had dose-dependent antiproliferative activity, with an $\mathrm{IC}_{50}$ value of $72 \mu \mathrm{M}$ after $24 \mathrm{~h}$ of incubation, and impaired metastasis of the cells via suppression of Epithelial-
Mesenchymal Transition (EMT). Another study pretreated A549 cells with $25 \mu \mathrm{M}$ kaempferol and found the EMT suppression induced by kaempferol was a result of inhibition of the phosphorylation of Smad3 at Threonine-179 by Akt1 [57]. Exposure of $\mathrm{H} 460$ cells to 30, 50 and $80 \mu \mathrm{M}$ kaempferol resulted in a dose-dependent increase in apoptosis via induction of caspase-3, apoptosis-inducing factor (AIF) and increasing antioxidant enzymes [58].

Hesperidin ( $(2 S)-5$-hydroxy-2-(3-hydroxy-4methoxyphenyl)-7-[(2S,3R,4S,5S,6R)-3,4,5-trihydroxy6-[[(2R,3R,4R,5R,6S)-3,4,5-trihydroxy-6-methyloxan-2yl]oxymethyl]oxan-2-yl]oxy-2,3-dihydrochromen-4-one) is a flavanone that is found in many citrus fruits [59] (refer to Fig. 2 for structure). A study by Cincin et al. [60] found that 5$50 \mu \mathrm{M}$ hesperidin caused a dose- and time-dependent inhibition of proliferation and induction of apoptosis via loss of mitochondrial membrane potential, activation of caspase-3, and affecting the fibroblast growth factor and NF- $\mathrm{KB}$ signal transduction pathways in A549 and NCI-H358 cells. Hesperidin $(5-100 \mu \mathrm{M})$ showed a significant inhibitory effect on tyrosine kinase inhibitors (TKI)- resistant cell line, H1993, while almost having no effect on the TKI- sensitive cell line, H2073 [61]. The study did not speculate on the method of this inhibitory effect.

Acacetin (5,7-dihydroxy-40 -methoxyflavone) is a flavonoid that has been studied for its effect on lung cancer cells (refer to Fig. 2 for structure). Chien et al. [62] administered $10-30 \mu \mathrm{M}$ acacetin to A549 which resulted in significant inhibition of cell viability. Further exposure of the A549 cells to $0,1,2.5$, and $5 \mu \mathrm{M}$ acacetin showed an inhibition of invasion and migration thought to be due to disruption of several signalling pathways and kinases including AP-1, NF- $\mathrm{kB}$, cFos, c-Jun, mixed lineage protein kinase 3 (MLK3), mitogenactivated protein kinases 3/6 (MAPK3/6), and p38a MAPK.

\section{Phenolic acids}

Phenolic acids can be subdivided into two major subgroups, namely hydroxybenzoic acids and hydroxycinnamic acids [3]. Refer to Fig. 3 for the structures of phenolic compounds discussed below and refer to Table 2 for the list of studies discussed below.

The hydroxycinnamic acid derivatives, tatariside $\mathrm{B}, \mathrm{C}$ and $\mathrm{D}$, are isolated from tartary buckwheat (Fagopyrum tataricum) [63]. The tatarisides B-D showed significant cytotoxicity effects against human lung adenocarcinoma A-549 cells, with recorded $\mathrm{IC}_{50}$ values of $18.3 \mu \mathrm{g} / \mathrm{mL}, 6.44 \mu \mathrm{g} / \mathrm{mL}$, and $2.83 \mu \mathrm{g} / \mathrm{mL}$, respectively [63].

A study of the effect of 4-O-(2"-O-acetyl-6"-O-pcoumaroyl- $\beta$-d-glucopyranosyl)-p-coumaric acid (4-ACGC) against several lung cancer cell lines, including A549, NCIH1299, and HCC827 showed that 4-ACGC caused dose-dependent, anti-proliferative activity between 10 and $100 \mu \mathrm{g} /$ 


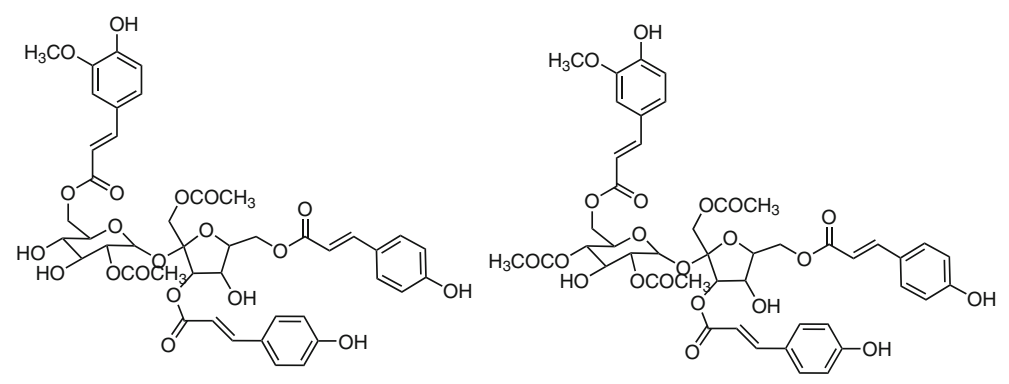

TATARISIDE B<smiles>CC(=O)OC(Oc1ccc(/C=C/C(=O)O)cc1)C(O)(CO)COC(=O)/C=C/c1ccc(O)cc1</smiles><smiles>COc1cc(/C=C/C(=O)OCC2OC(CO)(CO)C(OC(=O)/C=C/c3ccc(O)cc3)C2O)ccc1O</smiles>

TATARISIDE D<smiles>O=C(O)/C=C/c1ccc(O)cc1</smiles>

p-COUMARIC ACID<smiles>O=C(O)c1ccccc1O</smiles>

SALICYLIC ACID<smiles>O=C(O)c1cc(O)c(O)c(O)c1</smiles><smiles>O=C(O)/C=C/c1ccc(O)c(O)c1</smiles>

CAFFEIC ACID<smiles>COc1cc(/C=C/C(=O)O)ccc1O</smiles>

FERULIC ACID

Fig. 3 List of phenolic acids and their chemical structures

$\mathrm{mL}$, with $\mathrm{IC}_{50}$ values of $37.73 \mu \mathrm{g} / \mathrm{mL}$ (A549), $50.6 \mu \mathrm{g} / \mathrm{mL}$ (NCI-H1299), and $62.0 \mu \mathrm{g} / \mathrm{mL}$ (HCC827) [64]. This suggests that 4-ACGC causes upregulation of caspase-3 \& 9, Bcl-2associated death promoter (Bad), and Bax while also downregulating Bcl-2 [64].

p-Coumaric acid (4-hydroxycinnamic acid) is biologically synthesised through the shikimate pathway with phenylalanine and tyrosine as precursors [65]. p-Coumaric acid (50-
$100 \mu \mathrm{M}$ ) showed a significant inhibitory effect on the proliferation of the TKI-resistant cell line, H1993, while only moderately affecting the TKI- sensitive cell line, H2073 [61]. The study did not speculate on the method of this inhibitory effect. Nasr Bouzaiene et al. [66] found that p-Coumaric acid (50$1000 \mu \mathrm{M}$ ) caused up to a $55 \%$ reduction in the proliferation of A549 cells in a dose-dependent manner. p-Coumaric acid (50$200 \mu \mathrm{M})$ also caused a significant decrease in the production

Table 2 List of phenolic acids

\begin{tabular}{|c|c|c|c|c|}
\hline Phenolic acid name & Concentration & Cell line & Mechanisms & Reference \\
\hline Tatariside B & $18.3 \mu \mathrm{g} / \mathrm{mL}$ & A549 & Inhibition of proliferation of cell line & [63] \\
\hline Tatariside $\mathrm{C}$ & $6.44 \mu \mathrm{g} / \mathrm{mL}$ & & & \\
\hline Tatariside D & $2.83 \mu \mathrm{g} / \mathrm{mL}$ & & & \\
\hline \multirow[t]{3}{*}{ 4-ACGC } & $37.73 \mu \mathrm{g} / \mathrm{mL}$ & A549 & Upregulation of caspase-3 \& 9, Bad, and Bax & {$[64]$} \\
\hline & $50.6 \mu \mathrm{g} / \mathrm{mL}$ & NCI-H1299 & down-regulation of $\mathrm{Bcl}-2$ & \\
\hline & $62.0 \mu \mathrm{g} / \mathrm{mL}$ & HCC 827 & & \\
\hline \multirow[t]{2}{*}{ p-Coumaric acid } & $50-100 \mu \mathrm{M}$ & H1993 & Suppression of cell viability & {$[61]$} \\
\hline & $50-1000 \mu \mathrm{M}$ & A549 & $\begin{array}{l}\text { Decreased proliferation, superoxide anion production, cell adhesion, } \\
\text { and cell migration }\end{array}$ & {$[66]$} \\
\hline Salicylic acid & $6.0 \mathrm{mM}$ & A549 & Proapoptotic, antiproliferative, and cytotoxic effects & [68] \\
\hline \multirow[t]{4}{*}{ Gallic acid } & $10-50 \mu \mathrm{M}$ & Calu 6 & Depletion of glutathione and increasing ROS levels & [70] \\
\hline & $100-200 \mu \mathrm{M}$ & A549 & & \\
\hline & $50 \mu \mathrm{M}$ & H1975 & $\begin{array}{l}\text { Inhibition of Src-mediated STAT3 phosphorylation, leading to downregulation } \\
\text { of STAT3 target genes (Bcl2 and cyclin D) causing apoptosis and cell cycle arrest }\end{array}$ & [71] \\
\hline & $5 \mu \mathrm{M}$ & H1993 & $\begin{array}{l}\text { Inhibition of Src-mediated STAT3 phosphorylation, leading to downregulation of } \\
\text { STAT3 target genes (Bcl2 and cyclin D) causing apoptosis and cell cycle arrest }\end{array}$ & {$[61]$} \\
\hline Caffeic acid & $50-1000 \mu \mathrm{M}$ & A549 & Decreased proliferation, superoxide anion production, cell adhesion, and cell migration & {$[66]$} \\
\hline Ferulic acid & $50-1000 \mu \mathrm{M}$ & A549 & Decreased proliferation, superoxide anion production, cell adhesion, and cell migration & {$[66]$} \\
\hline
\end{tabular}


of superoxide anion, cell adhesion, and tumour cell migration in A549 cells in a dose-dependent manner [66].

Salicylic acid (2-Hydroxybenzoic acid) is a phenolic acid that was first isolated from white willow (Salix alba) and has demonstrated anti-inflammatory properties [67]. Vejselova and Kutlu [68] discovered that salicylic acid had proapoptotic, antiproliferative, and cytotoxic effects on A549 cells with a recorded $\mathrm{IC}_{50}$ of $6.0 \mathrm{mM}$ after $24 \mathrm{~h}$.

Gallic acid (3,4,5-trihydroxybenzoic acid) is a phenolic acid from various sources such as green tea, raspberries, blueberries, bananas, and grapes [69]. Gallic acid has been shown to inhibit cell growth and induce cell death in Calu $6\left(\mathrm{IC}_{50} 10-50 \mu \mathrm{M}\right)$ and $\mathrm{A} 549$ ( $\left.\mathrm{IC}_{50} 100-200 \mu \mathrm{M}\right)$ cells by depleting glutathione and increasing reactive oxygen species (ROS) levels [70]. Gallic acid was also found to have an anti-proliferative effect on TKI-resistant cell line, $\mathrm{H} 1975$, at $50 \mu \mathrm{M}$ while not affecting TKI- sensitive cell lines [71]. Another study also found that gallic acid $(5 \mu \mathrm{M})$ showed a strong inhibitory effect on the TKI- resistant cell line, H1993, while sparing the TKI- sensitive cell lines [61]. Both studies suggest that gallic acid inhibits TKIresistant cell line proliferation through inhibition of Srcmediated signal transducer and activator of transcription protein 3 (STAT3) phosphorylation, leading to downregulation of STAT3 target genes (Bcl2 and cyclin D) causing apoptosis and cell cycle arrest $[61,71]$.

Caffeic acid (50-1000 $\mu \mathrm{M})$ caused a significant reduction in A549 cell viability in a dose-dependent manner [66]. Caffeic acid (50-200 $\mu \mathrm{M})$ also caused a significant decrease in the production of superoxide anion, cell adhesion, and tumour cell migration in A549 cells in a dose-dependent manner [66].

Ferulic acid $(50-1000 \mu \mathrm{M})$ caused a significant reduction in A549 cell viability in a dose-dependent manner [66]. Ferulic acid (50-200 $\mu \mathrm{M})$ also caused a significant decrease in the production of superoxide anion, cell adhesion, and tumour cell migration in A549 cells in a dose-dependent manner [66].

\section{Diphenylalkaloids}

Diphenylalkaloids are alkaloids with one or more diphenyl ether linkages [72]. Diphenylalkaloids can be further classified, depending on the length of the carbon chain between two aromatic rings, into diphenylheptanoids, diphenylpentanoids, and other diphenylalkanoids [73]. Refer to Fig. 4 for structure and Table 3 for the list of studies discussed below.

Curcumin ( $(1 E, 6 E)-1,7-\mathrm{B}$ is ( 4 -hydroxy-3methoxyphenyl)-1,6-heptadiene-3,5-dione) consists of two groups of diphenylalkaloids, namely diphenylheptanoids (or diarylheptanoids) and diphenylpentanoids (or diarylpentanoids) $[74,75]$. Curcumin is a hydrophobic polyphenol responsible for the yellow colour of the Indian spice turmeric (Curcuma longa) [76]. Curcumin is considered the most active constituent of turmeric comprising $2-5 \%$ of turmeric preparations. Turmeric has been used for over 5000 years in the traditional Indian medicine system known as Ayurveda [77]. Recent evidence suggests that curcumin has both antioxidant and anti-inflammatory properties [78, 79].

Curcumin has been shown to modulate cytokines, enzymes, growth factors, kinases, and transcription factors [80]. Several researchers investigated the anticancer properties of curcumin. A study by Lin et al. [81] found that curcumin at a concentration of $30 \mu \mathrm{M}$ activated caspase- 3 resulting in DNA damage and endoplasmic reticulum (ER) stress and mitochondrial-dependent-induced apoptosis in human lung cancer A-549 cells. The effect of curcumin was assessed on two human lung cancer cell lines, namely A549 (TP53 proficient) and the large cell lung carcinoma cell line H1299 (TP53 null mutant) [82]. Curcumin inhibited the growth and induced apoptosis in a concentration dependent manner in both cell lines. Exposure of the cell lines to $40-50 \mu \mathrm{M}$ resulted in a $50 \%$ reduction in cell viability, while a concentration of $160 \mu \mathrm{M}$ lead to a more significant $95 \%$ reduction in the viability of the cells. Since curcumin induced apoptosis occurred in both the TP53 proficient (A549) and the TP53 deficient (H1299) cell line it can be deduced that curcumin induces its growth inhibitory effect in a TP53-independent manner. Curcumin was also shown to inhibit the invasion and migration of A549 cells through the inhibition of MMP-2 and matrix metalloproteinase-9 (MMP-9) and Vascular Endothelial Growth Factor (VEGF) at concentrations of 10 and $20 \mu \mathrm{M}$ [83]. Wu et al. [84] studied the effects of curcumin on human non-small cell lung cancer NCI-H460 cells. They found that curcumin had a dose-dependent cytotoxic effect on the NCI$\mathrm{H} 460$ cells with a concentration of $30 \mu \mathrm{M}$ leading to cell death in $95 \%$ of the cells. The study ascertained that curcumin caused apoptosis in the NCI-H460 cells due to mitochondrial membrane potential loss and subsequent caspase- 3 activation, together with the activation of FAS/caspase-8 (extrinsic) pathway, ER stress proteins, growth arrest- and DNA damageinducible gene 153 (GADD 153) and glucose-regulated protein 78 (GRP78). Curcumin (5-20 $\mu \mathrm{mol} / \mathrm{L})$ was also shown to concentration-dependently inhibit human lung adenocarcinoma cells (CL1-5) by invasion and metastasis via the upregulation of the DnaJ-like heat shock protein 40 (HLJ1) associated with tumour suppression, via activation of the $\mathrm{JNK} / \mathrm{JunD}$ pathway [85]. It was also shown that curcumin caused significant growth inhibition of the human lung cancer cell PC-9, inducing G1 and S phase arrests in cell-cycle regulation and apoptosis in a TP53-independent manner [86]. Growth arrest and apoptosis was most significantly observed at a concentration of $50 \mu \mathrm{M}$, where the percentage of viable cells $24 \mathrm{~h}$ after treatment was $47.5 \%$ of the control. It was found that the apoptosis was driven by the upregulation of growth arrestand DNA damage-inducible gene 45 (GADD 45) and GADD 153. Similarly, curcumin was shown to induce apoptosis in human lung squamous cell carcinoma (SK-MES-1) 
Fig. 4 Curcumin structure<smiles>COc1cc(/C=C/C(=O)/C=C(O)/C=C/c2ccc(O)c(OC)c2)ccc1O</smiles>

CURCUMIN

via upregulation of several genes including proliferating cell nuclear antigen (PCNA), DNA polymerase lambda (POLL), MutY DNA Glycosylase (MUTYH), signal transducer and activator of transcription 5a (STAT5A), and AKT1, and the downregulation of mitogen-activated protein kinase 1 (MAPK1), arrestin beta 2 (ARRB2), protein tyrosine kinase 2 (PTK2), mitogen-activated protein kinase 14 (MAPK14), vascular endothelial growth factor A (VEGFA), and nuclear factor kappa b subunit 1 (NFKB1); the most significant which was found at $15 \mu \mathrm{mol} / \mathrm{L}$ [87].

\section{Stilbenes}

Stilbenes are phenolic compounds with a core $\mathrm{C}_{6}-\mathrm{C}_{2}-\mathrm{C}_{6}$ structural feature. They are phytoalexins usually produced by plants in response to fungal, bacterial or viral attacks [88]. Refer to Fig. 5 for the structures of the stilbenes and Table 4 for the list of studies discussed below.

Resveratrol (trans-3,5,4'-trihydroxystilbene) is the most common natural stilbene found abundantly in a large number of fruits and vegetables, most notably grapes [89]. It has antiinflammatory [90], anti-oxidative [91], proapoptotic and cell cycle arrest [92] properties. A study by Wang et al. [93] found that $20 \mu \mathrm{M}$ resveratrol suppressed invasion and metastasis of A549 cells by preventing transforming growth factor beta 1 (TGF- $\beta 1$ ) induced EMT. Another study exposed A549 cells to 4-64 $\mu \mathrm{M}$ resveratrol which resulted in inhibition of growth $\left(\mathrm{IC}_{50} 8.9 \mu \mathrm{M}\right)$ and apoptosis induced via caspase-3 activation [94]. Resveratrol $(1-10 \mu \mathrm{M})$ showed a significant inhibitory effect on TKI- resistant cell line, H1993, while almost having no effect on the TKI- sensitive cell line, H2073 [61]. The study did not speculate on the method of this inhibitory effect.

Pterostilbene (trans-3,5-dimethoxy-4-hydroxystilbene) is an analogue of resveratrol that occurs naturally and which has similar biological effects [95]. Schneider et al. [96] investigated the effect of pterostilbene $(10-100 \mu \mathrm{M})$ on two lung cancer cell lines, NCI-H460 and SK-MES-1. Pterostilbene caused a decrease in cell viability, especially for concentrations more than $20 \mu \mathrm{M}$, and increased apoptosis and caspase 3 \& 7 activity.

\section{Bioavailability of phenolic compounds}

These studies of the biological activity of phenolic compounds against cancer cells shows that there's great promise for their therapeutic application to treat cancer, but one hindrance to this use is the low absorption they exhibit. The low absorption stems from decreased solubility and decreased stability [97].

Dietary intake of phenolic acids are estimated to range from $200 \mathrm{mg}$ /day up to $1198.6 \mathrm{mg}$ /day [3, 98]. The oral bioavailability of tea catechins seems to be very low, with plasma concentrations being between 5 to 50 times lower than what is required to replicate findings in vitro [99]. Another compounding problem is that some phenolic compounds such as quercetin are present in our diets at very low quantities,

Table 3 List of studies where curcumin showed anticancer activity against various lung cancer cell lines

\begin{tabular}{lllll}
\hline Diphenylalkaloid & Concentration & Cell line & Mechanisms & Reference \\
\hline Curcumin & $30 \mu \mathrm{M}$ & A-549 & Caspase-3 induced apoptosis. TP53-independent apoptosis & [81] \\
& $40-50,160 \mu \mathrm{M}$ & A549 & TP53-independent induction of apoptosis & \\
& H1299 & MMP 2\&9 mediated inhibition of invasion and metastasis & [83] \\
& $10-20 \mu \mathrm{M}$ & A549 & Caspase-3 \& 8 induced apoptosis & [84] \\
& $30 \mu \mathrm{M}$ & NCI-H460 & Upregulation of tumour suppressor HLJ1 & [85] \\
& $5-20 \mu \mathrm{mol} / \mathrm{L}$ & CL1-5 & Apoptosis via upregulation of GADD 45 and 153 & Up7] \\
\hline
\end{tabular}


Fig. 5 List of stilbenes and their chemical structures<smiles>Oc1ccc(/C=C/c2cc(O)cc(O)c2)cc1</smiles>

RESVERATROL<smiles>COc1cc(/C=C/c2ccc(O)cc2)cc(OC)c1</smiles>

PTEROSTILBENE approximately $20 \pm 5 \mathrm{mg}$ of your daily dietary intake [100]. Pharmacokinetics studies has suggested that absorption of quercetin in humans following a single oral dose can be as low as $2 \%$ [101]. A study by Hollman et al. [102] showed that when humans received $68 \mathrm{mg}$ quercetin equivalents (nearly twice the estimated maximum flavonol intake) the maximum plasma concentration was only $0.74 \mu \mathrm{mol} / \mathrm{L}$. Zheng et al. [45] demonstrated that administration of $0.74 \mu \mathrm{mol} / \mathrm{L}$ quercetin caused 5,10 , and $30 \%$ inhibition in growth of A549 cells after 24,48 , and $72 \mathrm{~h}$ period, respectively. It doesn't fare much better for diphenylalkaloids such as curcumin either. Many studies have shown that curcumin has a poor oral bioavailability due to low absorption, increased metabolism, and its swift elimination from the body. Yang et al. [103] found the oral bioavailability of curcumin to be $1 \%$ when they compared the maximum serum concentrations achieved after intravenousand oral administration of curcumin, $0.36 \pm 0.05 \mu \mathrm{g} / \mathrm{mL}$ and $0.06 \pm 0.01 \mu \mathrm{g} / \mathrm{mL}$, respectively. Another study showed that when 3.6-12 g C complex is taken per day for a week or longer, that the plasma levels of curcumin remains at or below $25 \mathrm{nmol}$ [104]. Siviero et al. [105] reported that after intraperitoneal injection of $100 \mathrm{mg} / \mathrm{kg}$ of carbon-14 curcumin, the following distribution was obtained: brain $2.9 \pm 0.4 \mathrm{nmol} / \mathrm{g}$, muscle $8.4 \pm 6.0 \mathrm{nmol} / \mathrm{g}$, heart $9.1 \pm 1.1 \mathrm{nmol} / \mathrm{g}$, lung $16 \pm$ $3 \mathrm{nmol} / \mathrm{g}$, liver $73 \pm 20 \mathrm{nmol} / \mathrm{g}$, kidney $78 \pm 3 \mathrm{nmol} / \mathrm{g}$, and intestinal mucosa $200 \pm 23 \mathrm{nmol} / \mathrm{g}$. This indicates that the bulk of curcumin goes towards the tissue of the intestine.

Resveratrol on the other hand has relatively high oral absorption (at least $70 \%$ absorbed), but has a low oral bioavailability [106]. It is postulated that the low oral bioavailability could be due to the rapid sulfate conjugation of resveratrol by the liver/intestine [106]. Several studies concluded that after oral administration of approximately $25 \mathrm{mg}$ resveratrol, the plasma concentration of the free form of resveratrol was between 1 and $5 \mathrm{ng} / \mathrm{ml}$ [107-110].
The in vitro studies show what the phenolic compounds can do once accumulated at the site of action and in sufficient concentration. However, in reality concerning oral ingestion, such as when you are trying to get the phenolic compounds from your diet. The phenolic compounds have to navigate many obstacles to get to the bloodstream and ultimately the site of action. The phenolic compounds face the high acidity environment of the stomach which can cause degradation and uncontrolled release which, in turn, can cause decreased absorption from the intestines [97]. Several great reviews have been written on the topic of bioavailability of phenolic compounds, which can aid the reader with further information $[111,112]$. Therefore, it is not possible to obtain, through the diet alone, the concentration of phenolic compounds necessary to have the effects described in the previous section. This is one of the questions proposed by Rasouli et al., whether it is possible to achieve the concentration of phenolic compounds in vivo in order to replicate the effects seen in vitro [113]. It is the purpose of the next section to propose that by transporting the phenolic compounds in a way that helps successfully traverse and protect it from these obstacles, it may be possible to achieve similar effects without needing phenolic compounds in the micromolar range.

\section{Drug delivery}

\section{Nanoparticulate delivery systems}

Nanoparticles and liposomes are useful strategies to overcome the poor absorption, rapid metabolism, and elimination inherent in most natural products; helping to increase their bioavailability and target specific sites, such as the lung. This section will be looking at studies carried out on delivery systems

Table 4 List of stilbenes with potential anticancer activity against various cell cancer lines

\begin{tabular}{|c|c|c|c|c|}
\hline Stilbenes name & Concentration & Cell lines & Mechanisms & References \\
\hline \multirow[t]{3}{*}{ Resveratrol } & $20 \mu \mathrm{M}$ & A549 & Suppressed invasion and metastasis by preventing TGF- $\beta 1$ induced EMT & [93] \\
\hline & $4-64 \mu \mathrm{M}$ & A549 & Inhibition of growth and apoptosis induced via caspase 3 activation & [94] \\
\hline & $1-10 \mu \mathrm{M}$ & H1993 & Suppression of cell viability & {$[61]$} \\
\hline Pterostilbene & $10-100 \mu \mathrm{M}$ & NCI-H460 SK-MES-1 & Decrease in cell viability and increased apoptosis and caspase- $3 \& 7$ activity & [96] \\
\hline
\end{tabular}


Table 5 List of phenolic compounds and the polymeric nanoparticles used in their delivery

\begin{tabular}{|c|c|c|c|}
\hline Nanoparticulate system & Phenolic compound & Effect & Reference \\
\hline $\begin{array}{l}\text { PLGA } \\
\text { PLGA-PEG }\end{array}$ & Curcumin & $\begin{array}{l}\text { PLGA and PLGA-PEG nanoparticles: } \\
\text { - increased the peak concentration of curcumin by } 2.9 \text { - and 7.4-fold } \\
\text { - increased the half-life of the curcumin from } 1 \mathrm{~h} \text { to } 4 \mathrm{~h} \text { (PLGA) and } 6 \mathrm{~h} \text { (PLGA-PEG) } \\
\text { - enhanced the oral bioavailability of curcumin by } 15.6 \text { - and } 55.4 \text {-fold, respectively }\end{array}$ & [123] \\
\hline $\begin{array}{l}\text { Chitosan Gelatin } \\
\text { Hyaluronan }\end{array}$ & Curcumin & $\begin{array}{l}\text { Polymeric chitosan, gelatin, and hyaluronan nanoparticles: } \\
\text { - All showed enhanced apoptotic effects of } 45,40 \text { and } 32 \% \text {, respectively, as opposed } \\
\text { to pure curcumin }(>20 \%) \text { on A549 cells }\end{array}$ & {$[124]$} \\
\hline Chitosan & naringenin & $\begin{array}{l}\text { naringenin encapsulated chitosan nanoparticles (NAR/CS NPs): } \\
\text { - caused a statistically significant dose-dependent decrease in cell viability in A549 cells } \\
\text { as compared with free naringenin, without affecting the normal 3T3 cells }\end{array}$ & {$[126]$} \\
\hline Gelatin & Resveratrol & $\begin{array}{l}\text { Resveratrol encapsulated in gelatin nanoparticles: } \\
\text { - induced cell death in human lung cancer cells NCI-H460 by changing the expression } \\
\text { of TP53, p21, caspase-3, Bax, Bcl-2 and NF-kB }\end{array}$ & [119] \\
\hline Gelatin & Resveratrol & $\begin{array}{l}\text { Resveratrol encapsulated gelatin nanoparticles (R-GNPs): } \\
\text { - improved cellular uptake and superior bioavailability, decreasing cell viability, } \\
\text { mitochondrial membrane potential and increasing cytotoxicity, DNA damage and } \\
\text { intracellular ROS levels as compared to free resveratrol in NCI-H460 cells }\end{array}$ & {$[127]$} \\
\hline PLGA & EGCG & $\begin{array}{l}\text { The EGCG-encapsulated PLGA nanoparticles: } \\
\text { - decreased } \text { IC }_{50} \text { of EGCG from } 60 \mu \mathrm{M} \text { (free EGCG) to } 9 \mu \mathrm{M} \text { (encapsulated-EGCG) } \\
\text { - enhanced the sensitivity of the A549 cells to cisplatin by reducing the dose of cisplatin } \\
\text { required by up to } 20 \text {-fold }\end{array}$ & {$[128]$} \\
\hline
\end{tabular}

using polymeric nanoparticles. For a more comprehensive list of delivery systems utilising other nanoparticulate systems, such as liposomes, micelles, dendrimers, etc. refer to the review by Loira-Pastoriza, Todoroff and Vanbever [110].

Polymeric nanoparticles refers to colloidal systems with spherical or irregular shape that either encapsulates or entraps a biologically active substance [114]. Numerous biodegradable polymers, both synthetic and natural, can be utilised to create polymeric nanoparticles, including polycaprolactone (PCL), polylactic acid (PLA), poly (lactic-co-glycolic acid) (PLGA), chitosan and gelatin [115]. The US Food and Drug Administration (FDA) have approved PLA and PLGA for human applications. PLA and PLGA are broken down in an organism into their biodegradable biocompatible monomeric building blocks, lactic and glycolic acid [115]. When PLA and PLGA are administered intravenously, they are normally quickly cleared by the immune system of the host [116]. To combat this and increase the circulation time, nanoparticles are often coated with poly(ethylene glycol) (PEG), a polymer that can aid in evading clearance by the immune system [117]. Chitosan is a natural polycationic linear polysaccharide, that has been shown to be mucoadhesive, non-immunogenic and non-toxic [118]. Gelatin is a protein based biopolymer that's highly biocompatible and biodegradable with low toxicity and low antigenicity [119]. The advantages of polymeric nanoparticles include controllable physico-chemical properties, high stability, homogenous size distribution, high drug encapsulation, and controllable drug release [120].

Polymeric nanoparticles have been extensively studied for their drug delivery capacity (refer to table 5 for list of studies discussed below). PLGA is, due to FDA approval, the most popular polymer used for nanoparticle delivery. It is safe and highly stable in colloidal suspensions and has been shown to have controlled release properties [121]. PLGA nanoparticles with or without chitosan coating has been shown to be cytocompatible with A549 cells as high as $5 \mathrm{mg} / \mathrm{mL}$ [122]. Khalil et al. [123] showed that orally administered PLGA and PLGA-PEG nanoparticles increases drug absorption (increased bioavailability),causes sustained drug release, and increases the half-life of the encapsulated drug. PLGA and PLGA-PEG nanoparticles increased the peak concentration of curcumin by 2.9- and 7.4-fold, increasing the peak concentration of free curcumin from $4.066 \pm 0.564 \mathrm{ng} / \mathrm{ml}$ to $11.783 \pm$ $0.454 \mathrm{ng} / \mathrm{ml}$ and $29.778 \pm 4.632 \mathrm{ng} / \mathrm{ml}$ for PLGA and PLGAPEG nanoparticles, respectively [123]. The PLGA and PLGA-PEG nanoparticles also increased the half-life of the curcumin from $1 \mathrm{~h}$ to $4 \mathrm{~h}$ and $6 \mathrm{~h}$, for free curcumin, PLGA, PLGA-PEG nanoparticles, respectively [123]. The PLGA and PLGA-PEG nanoparticles enhanced the oral bioavailability of curcumin by 15.6- and 55.4-fold, respectively [123]. Teong et al. [124] encapsulated curcumin in polymeric chitosan, gelatin, and hyaluronan nanoparticles with an encapsulation efficiency of 81,67 , and $78 \%$, respectively. The curcuminencapsulated- chitosan, gelatin, and hyaluronan nanoparticles all showed enhanced apoptotic effects of 45, 40 and 32\%, respectively, as opposed to pure curcumin ( $>20 \%$ ) on A549 cells [124]. When administered intravenously to rats, a significant amount of curcumin encapsulated into PLGA nanoparticles were found in the lungs [125]. Kumar et al. [126] used in vitro studies to investigate the effects of naringenin encapsulated chitosan nanoparticles (NAR/CS NPs) on A549 lung cancer cells and normal mouse fibroblast cells (3T3). The 
results showed that the NAR/CS NPs caused a statistically significant dose-dependent decrease in cell viability in A549 cells as compared with free naringenin, without affecting the normal 3T3 cells [126]. Resveratrol encapsulated in gelatin nanoparticles was shown to induce cell death in human lung cancer cells NCI-H460 by changing the expression of TP53, p21, caspase-3, Bax, Bcl-2 and NF-kB [119]. Previously, it was shown that resveratrol encapsulated gelatin nanoparticles (R-GNPs) had an improved cellular uptake and superior bioavailability, decreasing cell viability, mitochondrial membrane potential and increasing cytotoxicity, DNA damage and intracellular ROS levels as compared to free resveratrol in NCIH460 cells [127]. Singh et al. [128] encapsulated EGCG in PLGA nanoparticles and assessed it on human lung cancer A549 cells. The EGCG-encapsulated PLGA nanoparticles showed an $\mathrm{IC}_{50}$ of $9 \mu \mathrm{M}$ while the free EGCG showed an $\mathrm{IC}_{50}$ of $60 \mu \mathrm{M}$, meaning that the nanoparticles reduced the dose required to exert the same antiproliferative effect on the A549 cells by over 6 times [128]. The EGCG encapsulated PLGA nanoparticles also enhanced the sensitivity of the A549 cells to cisplatin by reducing the dose of cisplatin required by up to 20 fold [128]. Phenolic compounds delivered concomitantly with well-established chemotherapeutic drugs were shown to have a synergistic effect. Duan et al. [129] showed that the combined delivery of co-encapsulated curcumin and doxorubicin in poly(butyl cyanoacrylate) nanoparticles reversed the multidrug resistance of the breast cancer cell line (MC7) at a higher efficacy than the agents on its own or in separate nanoparticles. Another study showed that curcumin enhanced the apoptotic effect of doxorubicin while also supressing the adverse effects associated with it [130].

Popov et al. [131] found that administration via intratracheal instillation of fluticasone propionate (FP) encapsulated in poly(lactide)-based mucus-penetrating particles (MPP) for pulmonary delivery showed a higher local exposure to the lungs of rodents as compared to poly(lactide)-based mucoadhesive particles (MAP) and free-FP. PLGA nanoparticles coated with glycol chitosan was shown to be more readily absorbed onto A549 cells than the non-coated PLGA nanoparticles. The chitosancoated PLGA nanoparticles were found in the lungs up to $72 \mathrm{~h}$ after pulmonary administration, whereas noncoated PLGA nanoparticles were removed from the lungs $8 \mathrm{~h}$ after administration [132].

\section{Pulmonary delivery}

Pulmonary drug delivery allows for the non-invasive administration of a drug/bioactive compound via inhalation [133]. There are many advantages to delivering drugs via the lungs for both local and systemic treatment, including high bioavailability since the first pass metabolism is bypassed, rapid onset of action due to direct targeting at the site needed (lung cancer cells), self-administration (similar to how asthmatics use their inhalation devices) and non-invasiveness (which increases patient compliance) [134-136]. One of the biggest challenges for cancer chemotherapy is the non-specific targeting/ distribution of the anticancer agent and the severe side effects this produces [137]. Nanoparticle-mediated pulmonary delivery will aid in overcoming this obstacle through targeted delivery; reducing the dosage required to treat the cancer and reducing the amount of drug the healthy cells are being exposed to. However, spray-dried nanoparticles are incapable of depositing directly into the lungs since they get exhaled without settling in the alveoli due to their small size range $(<1 \mu \mathrm{m})$ [138]. The ideal range for particles to be able to deposit in the lung is between 1 and $5 \mu \mathrm{m}$ [139]. Nanoparticles can be made into the appropriate size via spray-drying the nanoparticles using excipients, such as leucine, to form microparticles. These microparticles can be delivered to the lungs through dry powder inhalers (DPIs). DPIs are portable solid powder delivery devices that are used without the aid of propellants [133]. DPIs often give a better stability profile for the loaded bioactive compound than aerosols or nebulizers [140].

Several drugs have been studied for both local and systemic pulmonary delivery [141]. Polymeric nanoparticles have been used for the pulmonary delivery of small molecules, genes and proteins/peptides [142-148]. However, studies using polymeric nanoparticle-mediated microparticles for pulmonary delivery of phenolic compounds are a little less ubiquitous in the literature.

Scutellarin, a flavone, was incorporated into polymeric microparticles based on poly(vinyl alcohol) (PVA), polyvinylpyrrolidone (PVP) and sodium hyaluronate [149]. The particles showed a median size of $1.95-2.83 \mu \mathrm{m}$, which is applicable for inhalation [149]. The particles were administered via pulmonary route and then assessed for bioavailability [149]. It was found that the pulmonary route caused the bioavailability of scutellarin to be $77 \%$, which was 30 fold higher than the oral route [149]. Studies has already shown that these polymeric nanoparticles can be used in combination with common anticancer drugs, such as cisplatin and doxorubicin, to either enhance their efficacy and/or attenuate their adverse effects. Liu et al. [150] prepared paclitaxel- oleic acid-conjugated chitosan nanoparticles (P-OA-CTS) and quercetin-oleic acid-conjugated chitosan nanoparticles (Q-OA-CTS) and then co-loaded both nanoparticles into microparticles by spray-drying the nanoparticles with hydroxypropyl- $\beta$-cyclodextrin, lactose, and mannitol as excipients. The microparticles obtained was shown to be in the ideal range of between 1 and $5 \mu \mathrm{m}$ with a slow release profile [150]. The study ascertained that intravenous delivery of the microspheres caused more accumulation of the encapsulated drug in the liver and kidney than in the lung, while pulmonary administration lead to a significant majority of the drug depositing in the lungs with minimal amounts accumulating in the other organs [150]. Furthermore, $6 \mathrm{~h}$ after pulmonary 
administration, paclitaxel and quercetin concentration in the lung remained high $(206.27 \mu \mathrm{g} / \mathrm{g})$ with comparatively low distribution in the liver $(8.82 \mu \mathrm{g} / \mathrm{g})$, spleen $(6.94 \mu \mathrm{g} / \mathrm{g})$, kidney $(5.01 \mu \mathrm{g} / \mathrm{g})$ and heart $(2.61 \mu \mathrm{g} / \mathrm{g})$ at the same time. Whereas, $6 \mathrm{~h}$ after intravenous delivery the concentration of paclitaxel and quercetin in all organs were $\leq 5 \mu \mathrm{g} / \mathrm{g}$. It was reported that quercetin helped increase the circulatory time of paclitaxel [150]. Combined, this shows that pulmonary delivery of microparticles not only improved the retention time of the drugs, but also allowed for the accumulation of the drug in the lung with only minimal amount of drug accumulating in other organs. This should lead to lower side-effects.

\section{Conclusion}

Phenolic compounds have huge potential in chemoprevention with a plethora of compounds showing promise in in vitro studies. However, the biggest drawback with using phenolic compounds is their low bioavailability due to several factors including low intrinsic activity, malabsorption, high rate of metabolism, inactivity of metabolic products and/or rapid elimination and clearance from the body [76]. It was shown that when the phenolic compounds were incorporated into polymeric nanoparticles, they enhanced the anticancer effects shown in vitro. Despite the ability of the polymeric nanoparticle to deliver the phenolic compounds via oral and intravenous administration, it is only natural to assess pulmonary delivery, especially for lung cancer. This is due to the many advantages that pulmonary delivery has. Although there are only a limited amount studies done on pulmonary delivery of phenolic compounds, they do show quite a lot of promise. It would be interesting to see where this field goes in the next few years.

Acknowledgements Ashley George Muller acknowledges the Erasmus Mundus programme, A European and South African Partnership on Heritage and Past+ (AESOP+) project, for the funding of his $\mathrm{PhD}$.

Open Access This article is distributed under the terms of the Creative Commons Attribution 4.0 International License (http:// creativecommons.org/licenses/by/4.0/), which permits unrestricted use, distribution, and reproduction in any medium, provided you give appropriate credit to the original author(s) and the source, provide a link to the Creative Commons license, and indicate if changes were made.

\section{References}

1. Cancer Research UK. Lung cancer statistics.2018. https://www. cancerresearchuk.org/health-professional/cancer-statistics/ statistics-by-cancer-type/lung-cancer\#heading-Zero. Accessed 13 Jul 2018.

2. Steward WP, Brown K. Cancer chemoprevention: a rapidly evolving field. Br J Cancer. 2013;109:1-7.
3. Heleno SA, Martins A, Queiroz MJRP, Ferreira ICFR. Bioactivity of phenolic acids: metabolites versus parent compounds: a review. Food Chem. 2015;173:501-13. https://doi.org/10.1016/j. foodchem.2014.10.057.

4. Reuter S, Gupta SC, Chaturvedi MM, Aggarwal BB. Oxidative stress, inflammation, and cancer: how are they linked? Free Radic Biol Med. 2010;49:1603-16.

5. Villegas L, Stidham T, Nozik-Grayck E. Oxidative stress and therapeutic development in lung diseases. J Pulm Respir Med. 2014;4: 194.

6. Lawenda BD, Kelly KM, Ladas EJ, Sagar SM, Vickers A, Blumberg JB. Should supplemental antioxidant administration be avoided during chemotherapy and radiation therapy? JNCI J Natl Cancer Inst. 2008; https://doi.org/10.1093/jnci/djn148

7. Dei Cas M, Ghidoni R. Cancer prevention and therapy with polyphenols: sphingolipid-mediated mechanisms. Nutrients. 2018;10: 940.

8. Fantini M, Benvenuto M, Masuelli L, Frajese GV, Tresoldi I, Modesti A, et al. In vitro and in vivo antitumoral effects of combinations of polyphenols, or polyphenols and anticancer drugs: perspectives on cancer treatment. Int J Mol Sci. MDPI. 2015;16: 9236-82.

9. Ignat I, Volf I, Popa VI. A critical review of methods for characterisation of polyphenolic compounds in fruits and vegetables. Food Chem. 2011;126:1821-35.

10. Sarker SD, Nahar L. Chemistry for pharmacy students. West Sussex: Wiley; 2007.

11. Vieira AR, Abar L, Vingeliene S, Chan DSM, Aune D, NavarroRosenblatt D, et al. Fruits, vegetables and lung cancer risk: a systematic review and meta-analysis. Ann Oncol. 2016; https:// doi.org/10.1093/annonc/mdv381

12. Amararathna M, Johnston MR, Rupasinghe HPV. Plant Polyphenols as Chemopreventive Agents for Lung Cancer. Int J Mol Sci.MDPI. 2016;17:1352.

13. Basli A, Belkacem N, Amrani I. Health Benefits of Phenolic Compounds Against Cancers. In: Soto-Hernández M, editor. Phenolic compounds - biological activity. London:InTechOpen. 2017:193-210.

14. Harborne JB. Classes and functions of secondary products from plants. In: Brown DE WJN, editor. Chemicals from plants - perspectives on plant secondary products. London: Imperial College Press; 1999. p. 1-25.

15. Harborne JB. The chemlcal basis of plant defense. In: Robbins CT PRT, editor. Plant defenses against Mammalian Herbivory. London: CRC Press; 1991. p. 46-59.

16. Shahidi F, Ambigaipalan P. Phenolics and polyphenolics in foods, beverages and spices: antioxidant activity and health effects $-\mathrm{a}$ review. J Funct Foods. 2015;18:820-97.

17. Pérez-Jiménez J, Neveu V, Vos F, Scalbert A. Systematic analysis of the content of 502 polyphenols in 452 foods and beverages: an application of the phenol-explorer database. J Agric Food Chem. 2010;58:4959-69.

18. Vallverdú-Queralt A, Regueiro J, Martínez-Huélamo M, Rinaldi Alvarenga JF, Leal LN, Lamuela-Raventos RM. A comprehensive study on the phenolic profile of widely used culinary herbs and spices: rosemary, thyme, oregano, cinnamon, cumin and bay. Food Chem. 2014;154:299-307.

19. Opara EI, Chohan M. Culinary herbs and spices: their bioactive properties, the contribution of polyphenols and the challenges in deducing their true health benefits. Int J Mol Sci. 2014;15:19183202.

20. Beecher GR. Overview of dietary flavonoids: omenclature, occurrence and intake. J Nutr. 2003;133:3244S-6S.

21. Dai J, Mumper RJ. Plant phenolics: extraction, analysis and their antioxidant and anticancer properties. Molecules. 2010;15:731352. 
22. Othman AI, El-Sawi MR, El-Missiry MA, Abukhalil MH. Epigallocatechin-3-gallate protects against diabetic cardiomyopathy through modulating the cardiometabolic risk factors, oxidative stress, inflammation, cell death and fibrosis in streptozotocinnicotinamide-induced diabetic rats. Biomed Pharmacother. 2017;94:362-73.

23. Zhong Y, Chiou YS, Pan MH, Shahidi F. Anti-inflammatory activity of lipophilic epigallocatechin gallate (EGCG) derivatives in LPS-stimulated murine macrophages. Food Chem. 2012;134: 742-8.

24. Navarro-Perán E, Cabezas-Herrera J, Sánchez-Del-Campo L, García-Cánovas F, Rodríguez-López JN. The anti-inflammatory and anti-cancer properties of epigallocatechin-3- gallate are mediated by folate cycle disruption, adenosine release and NF-KB suppression. Inflamm Res. 2008;57:472-8.

25. Kim C-H, Moon S-K. Epigallocatechin-3-gallate causes the p21/ WAF1-mediated G 1 -phase arrest of cell cycle and inhibits matrix metalloproteinase-9 expression in TNF-induced vascular smooth muscle cells. Arch Biochem Biophys. 2005;435:264-72.

26. Thangapazham RL, Singh AK, Sharma A, Warren J, Gaddipati JP, Maheshwari RK. Green tea polyphenols and its constituent epigallocatechin gallate inhibits proliferation of human breast cancer cells in vitro and in vivo. Cancer Lett. 2007;245:232-41.

27. Ahn WS, Huh SW, Bae SM, Lee IP, Lee JM, Namkoong SE, et al. A major constituent of green tea, EGCG, inhibits the growth of a human cervical cancer cell line, CaSki cells, through apoptosis, $\mathrm{G}(1)$ arrest, and regulation of gene expression. DNA Cell Biol. 2003;22:217-24.

28. Shankar S, Ganapathy S, Hingorani SR, Srivastava RK. EGCG inhibits growth, invasion, angiogenesis and metastasis of pancreatic cancer. Front Biosci. 2008;13:440-52.

29. Jin L, Li C, Xu Y, Wang LI, Liu J, Wang D, et al. Epigallocatechin gallate promotes $\mathrm{p} 53$ accumulation and activity via the inhibition of MDM2-mediated p53 ubiquitination in human lung cancer cells. Oncol Rep. 2013;29:1983-90.

30. Wang H, Bian S, Yang CS. Green tea polyphenol EGCG suppresses lung cancer cell growth through upregulating miR-210 expression caused by stabilizing HIF- $1 \alpha$. Carcinogenesis. 2011;32:1881-9.

31. Sadava D, Whitlock E, Kane SE. The green tea polyphenol, epigallocatechin-3-gallate inhibits telomerase and induces apoptosis in drug-resistant lung cancer cells. Biochem Biophys Res Commun. 2007;360:233-7.

32. Milligan SA, Burke P, Coleman DT, Bigelow RL, Steffan JJ, Carroll JL, et al. The green tea polyphenol EGCG potentiates the antiproliferative activity of c-met and epidermal growth factor receptor inhibitors in non-small cell lung cancer cells. Clin Cancer Res. 2009;15:4885-94.

33. Cromie MM, Gao W. Epigallocatechin-3-gallate enhances the therapeutic effects of Leptomycin B on human lung cancer A549 cells. Oxidative Med Cell Longev. 2015;2015:1-10. https://doi.org/10.1155/2015/217304.

34. Xiao H, Yang CS, Li S, Jin H, Ho C-T, Patel T. Monodemethylated polymethoxyflavones from sweet orange (Citrus sinensis) peel inhibit growth of human lung cancer cells by apoptosis. Mol Nutr Food Res. 2009;53:398-406.

35. Shiau RJ, Chen KY, Der Wen Y, Chuang CH, Yeh SL. Genistein and $\beta$-carotene enhance the growth-inhibitory effect of trichostatin a in A549 cells. Eur J Nutr. 2010;49:19-25.

36. Wu TC, Yang YC, Huang PR, Der Wen Y, Yeh SL. Genistein enhances the effect of trichostatin a on inhibition of A549 cell growth by increasing expression of TNF receptor-1. Toxicol Appl Pharmacol. 2012;262:247-54.

37. Gadgeel SM, Ali S, Philip PA, Wozniak A, Sarkar FH. Genistein enhances the effect of epidermal growth factor receptor tyrosine kinase inhibitors and inhibits nuclear factor kappa B in nonsmall cell lung cancer cell lines. Cancer. 2009;115:2165-76.

38. Zou H, Zhan S, Cao K. Apoptotic activity of genistein on human lung adenocarcinoma SPC-A-1 cells and preliminary exploration of its mechanisms using microarray. Biomed Pharmacother. 2008;62:583-9.

39. Li Y, Ahmed F, Ali S, Philip P a, Kucuk O, Sarkar FH. Inactivation of nuclear factor kappaB by soy isoflavone genistein contributes to increased apoptosis induced by chemotherapeutic agents in human cancer cells. Cancer Res. 2005;65:6934-42.

40. Arai Y, Watanabe S, Kimira M, Shimoi K, Mochizuki R, Kinae N. Dietary intakes of flavonols, flavones and isoflavones by Japanese women and the inverse correlation between quercetin intake and plasma LDL cholesterol concentration. J Nutr. 2000;130:224350 .

41. Khan N, Afaq F, Khusro FH, Mustafa Adhami V, Suh Y, Mukhtar H. Dual inhibition of phosphatidylinositol 3-kinase/Akt and mammalian target of rapamycin signaling in human nonsmall cell lung cancer cells by a dietary flavonoid fisetin. Int J Cancer. 2012;130: 1695-705.

42. Liao YC, Shih YW, Chao CH, Lee XY, Chiang TA. Involvement of the ERK signaling pathway in fisetin reduces invasion and migration in the human lung cancer cell line A549. J Agric Food Chem. 2009;57:8933-41.

43. Ma L, Wang R, Nan Y, Li W, Wang Q, Jin F, et al. Phloretin exhibits an anticancer effect and enhances the anticancer ability of cisplatin on non-small cell lung cancer cell lines by regulating expression of apoptotic pathways and matrix metalloproteinases. Int J Oncol. 2016;48:843-53.

44. Min J, Li X, Huang K, Tang H, Ding X, Qi C, et al. Phloretin induces apoptosis of non-small cell lung carcinoma A549 cells via JNK1/2 and p38 MAPK pathways. Oncol Rep. 2015;34:2871-9.

45. Zheng SY, Li Y, Jiang D, Zhao J, Ge JF. Anticancer effect and apoptosis induction by quercetin in the human lung cancer cell line A-549. Mol Med Rep. 2012;5:822-6.

46. Lee HJ, Lee HJ, Lee EO, Ko SG, Bae HS, Kim CH, et al. Mitochondria-cytochrome C-caspase- 9 cascade mediates isorhamnetin-induced apoptosis. Cancer Lett. 2008;270:342-53.

47. Ruan $\mathrm{Y}, \mathrm{Hu} \mathrm{K}$, Chen $\mathrm{H}$. Autophagy inhibition enhances isorhamnetin-induced mitochondria-dependent apoptosis in nonsmall cell lung cancer cells. Mol Med Rep. 2015;12:5796-806.

48. Zhang BY, Wang YM, Gong H, Zhao H, Lv XY, Yuan GH, et al. Isorhamnetin flavonoid synergistically enhances the anticancer activity and apoptosis induction by cis-platin and carboplatin in non-small cell lung carcinoma (NSCLC). Int J Clin Exp Pathol. 2015;8:25.

49. Liu B, Yu H, Baiyun R, Lu J, Li S, Bing Q, et al. Protective effects of dietary luteolin against mercuric chloride-induced lung injury in mice: involvement of AKT/Nrf2 and NF-kB pathways. Food Chem Toxicol. 2018;113:296-302.

50. Tan X, Liu B, Lu J, Li S, Baiyun R, Lv Y, et al. Dietary luteolin protects against $\mathrm{HgCl} 2$-induced renal injury via activation of $\mathrm{Nrf2}$ mediated signaling in rat. J Inorg Biochem. 2018;179:24-31.

51. Cai X, Ye T, Liu C, Lu W, Lu M, Zhang J, et al. Luteolin induced G2 phase cell cycle arrest and apoptosis on non-small cell lung cancer cells. Toxicol Vitr. 2011;25:1385-91.

52. Meng G, Chai K, Li X, Zhu Y, Huang W. Luteolin exerts proapoptotic effect and anti-migration effects on A549 lung adenocarcinoma cells through the activation of MEK/ERK signaling pathway. Chem Biol Interact. 2016;257:26-34.

53. Jiang ZQ, Li MH, Qin YM, Jiang HY, Zhang X, Wu MH. Luteolin inhibits tumorigenesis and induces apoptosis of non-small cell lung cancer cells via regulation of MicroRNA-34a-5p. Int J Mol Sci. 2018;19:447.

54. Lee YJ, Lim T, Han MS, Lee SH, Baek SH, Nan HY, et al. Anticancer effect of luteolin is mediated by downregulation of 
TAM receptor tyrosine kinases, but not interleukin- 8 , in non-small cell lung cancer cells. Oncol Rep. 2017;37:1219-26.

55. Ma L, Peng H, Li K, Zhao R, Li L, Yu Y, et al. Luteolin exerts an anticancer effect on NCI-H460 human non-small cell lung cancer cells through the induction of Sirt1-mediated apoptosis. Mol Med Rep. 2015;12:4196-202.

56. Hang M, Zhao F, Chen S, Sun Q, Zhang C. Kaempferol modulates the metastasis of human non-small cell lung cancer cells by inhibiting epithelial-mesenchymal transition 2015;10:267-271.

57. Jo E, Park SJ, Choi YS, Jeon WK, Kim BC. Kaempferol suppresses transforming growth factor- $\beta 1$-induced epithelial-tomesenchymal transition and migration of A549 lung cancer cells by inhibiting Akt1-mediated phosphorylation of Smad3 at threonine-179. Neoplasia. 2015;17:525-37.

58. Leung HWC, Lin CJ, Hour MJ, Yang WH, Wang MY, Lee HZ. Kaempferol induces apoptosis in human lung non-small carcinoma cells accompanied by an induction of antioxidant enzymes. Food Chem Toxicol. 2007;45:2005-13.

59. Ortuno A, Benavente-Garcia O, Castillo J, Alcaraz M, Vicente V, Del Rio JA. Beneficial action of Citrus flavonoids on multiple cancer-related biological pathways. Curr Cancer Drug Targets. 2007;7:795-809.

60. Cincin ZB, Unlu M, Kiran B, Bireller ES, Baran Y, Cakmakoglu B. Anti-proliferative, apoptotic and signal transduction effects of hesperidin in non-small cell lung cancer cells. Cell Oncol. 2015;38:195-204.

61. Jeong H, Phan AH, Choi JW. Anti-cancer effects of polyphenolic compounds in epidermal growth factor receptor tyrosine kinase inhibitor-resistant non-small cell lung cancer. Pharmacogn Mag. 2017;13:595-9.

62. Chien ST, Lin SS, Wang CK, Lee YB, Chen KS, Fong Y, et al. Acacetin inhibits the invasion and migration of human non-small cell lung cancer A549 cells by suppressing the p38 $\alpha$ MAPK signaling pathway. Mol Cell Biochem. 2011;350:135-48.

63. Zheng $\mathrm{C}, \mathrm{Hu} \mathrm{C}$, Ma X, Peng C, Zhang H, Qin L. Cytotoxic phenylpropanoid glycosides from Fagopyrum tataricum (L.) Gaertn. Food Chem. 2012;132:433-8.

64. Peng W, Wu JG, Jiang YB, Liu YJ, Sun T, Wu N, et al. Antitumor activity of 4-O-(2"-O-acetyl-6"-O-p-coumaroyl- $\beta$-dglucopyranosyl)-p-coumaric acid against lung cancers via mitochondrial-mediated apoptosis. Chem Biol Interact. 2015;233:8-13.

65. El-Seedi HR, El-Said AMA, Khalifa SAM, Göransson U, Bohlin L, Borg-Karlson A-K, et al. Biosynthesis, natural sources, dietary intake, pharmacokinetic properties, and biological activities of hydroxycinnamic acids. J Agric Food Chem. 2012;60:10877-95.

66. Nasr Bouzaiene N, Kilani Jaziri S, Kovacic H, Chekir-Ghedira L, Ghedira K, Luis J. The effects of caffeic, coumaric and ferulic acids on proliferation, superoxide production, adhesion and migration of human tumor cells in vitro. Eur J Pharmacol. 2015;766: 99-105.

67. Wu KK. Aspirin and salicylate: an old remedy with a new twist. Am Heart Assoc. 2000;102:2022-3.

68. Vejselova D, Kutlu HM. Inhibitory effects of salicylic acid on A549 human lung adenocarcinoma cell viability. Turkish J Biol. 2015;39:1-5.

69. Daglia M, Di Lorenzo A, Nabavi SF, Talas ZS, Nabavi SM. Polyphenols: well beyond the antioxidant capacity: gallic acid and related compounds as neuroprotective agents: you are what you eat! Curr Pharm Biotechnol. 2014;15:362-72.

70. You BR, Park WH. Gallic acid-induced lung cancer cell death is related to glutathione depletion as well as reactive oxygen species increase. Toxicol Vitr. 2010;24:1356-62.

71. Phan ANH, Hua TNM, Kim MK, Vo VTA, Choi JW, Kim $\mathrm{HW}$, et al. Gallic acid inhibition of Src-Stat3 signaling overcomes acquired resistance to EGF receptor tyrosine kinase inhibitors in advanced non-small cell lung cancer. Oncotarget. 2016;7:54702-13.

72. Manske RHF. The alkaloids: chemistry and physiology. 1st ed. New York: Academic Press; 2014.

73. Sun W, Wang S, Zhao W, Wu C, Guo S, Gao H, et al. Chemical constituents and biological research on plants in the genus Curcuma. Crit Rev Food Sci Nutr. 2017;57:1451-523.

74. Nahar L, Sarker SD. Phytochemistry of the genus Curcuma. In: Ravindran PN, NirmalBabu K, Sivaraman K, editors. Turmeric: the genus Curcuma. Florida: CRC Press; 2007. p. 71-106.

75. Li S, Yuan W, Deng Ping Wang G, Yang P. Chemical composition and product quality control of turmeric (Curcuma longa L.). 2011; 2, 28-54.

76. Anand P, Kunnumakkara AB, Newman RA, Aggarwal BB. Bioavailability of curcumin: problems and promises. Mol Pharm. 2007;4:807-18. https://doi.org/10.1021/mp700113r.

77. Aggarwal BB, Sundaram C, Malani N, Ichikawa H. Curcumin: the Indian solid gold. In: Aggarwal BB, Surh YJ, Shishodia S, editors. The molecular targets and therapeutic uses of curcumin in health and disease. Boston: Springer; 2007. p. 1-75.

78. Jha NS, Mishra S, Jha SK, Surolia A. Antioxidant activity and electrochemical elucidation of the enigmatic redox behavior of curcumin and its structurally modified analogues. Electrochim Acta. 2015;151:574-83. https://doi.org/10.1016/j.electacta.2014. 11.026 .

79. Liu L, Shang Y, Li M, Han X, Wang J, Wang J. Curcumin ameliorates asthmatic airway inflammation by activating nuclear factor-E2-related factor 2/haem oxygenase (HO)-1 signalling pathway. Clin Exp Pharmacol Physiol. 2015;42:520-9.

80. Chakraborty S, Ghosh U, Bhattacharyya NP, Bhattacharya RK, Roy M. Inhibition of telomerase activity and induction of apoptosis by curcumin in K-562 cells. Mutat Res - Fundam Mol Mech Mutagen. 2006;596:81-90.

81. Lin SS, Huang HP, Yang JS, Wu JY, Hsai TC, Lin CC, et al. DNA damage and endoplasmic reticulum stress mediated curcumininduced cell cycle arrest and apoptosis in human lung carcinoma A-549 cells through the activation caspases cascade- and mitochondrial-dependent pathway. Cancer Lett. 2008;272:7790. https://doi.org/10.1016/j.canlet.2008.06.031.

82. Pillai GR, Srivastava AS, Hassanein TI, Chauhan DP, Carrier E. Induction of apoptosis in human lung cancer cells by curcumin. Cancer Lett. 2004;208:163-70.

83. Lin SS, Lai KC, Hsu SC, Yang JS, Kuo CL, Lin JP, et al. Curcumin inhibits the migration and invasion of human A549 lung cancer cells through the inhibition of matrix metalloproteinase-2 and -9 and vascular endothelial growth factor (VEGF). Cancer Lett. 2009;285:127-33.

84. Wu SH, Hang LW, Yang JS, Chen HY, Lin HY, Chiang JH, et al. Curcumin induces apoptosis in human non-small cell lung cancer NCI-H460 cells through ER stress and caspase cascade- and mitochondria-dependent pathways. Anticancer Res. 2010;30: 2125-33.

85. Chen HW, Lee JY, Huang JY, Wang CC, Chen WJ, Su SF, et al. Curcumin inhibits lung Cancer cell invasion and metastasis through the tumor suppressor HLJ1. Cancer Res. 2008;68:7428 38.

86. Saha A, Kuzuhara T, Echigo N, Fujii A, Suganuma M, Fujiki H. Apoptosis of human lung cancer cells by curcumin mediated through up-regulation of "growth arrest and DNA damage inducible genes 45 and 153". Biol Pharm Bull. 2010;33:1291-9.

87. Zhao W, Wang Y, Wang Y, Gao N, Han Z, Yu H. Potential anticancer effect of curcumin in human lung squamous cell carcinoma. Thorac Cancer. 2015;6:508-16.

88. Del Rio D, Rodriguez-Mateos A, Spencer JPE, Tognolini M, Borges G, Crozier A. Dietary (poly)phenolics in human 
health: structures, bioavailability, and evidence of protective effects against chronic diseases. Antioxid Redox Signal. 2013;18:1818-92.

89. Francioso A, Mastromarino P, Restignoli R, Boffi A, d'Erme M, Mosca L. Improved stability of trans-resveratrol in aqueous solutions by Carboxymethylated (1,3/1,6)-beta-d-glucan. J Agric Food Chem. 2014;62:1520-5.

90. Donnelly LE, Newton R, Kennedy GE, Fenwick PS, Leung RHF, Ito $\mathrm{K}$, et al. Anti-inflammatory effects of resveratrol in lung epithelial cells: molecular mechanisms. Am J Physiol Lung Cell Mol Physiol. 2004;287:L774-83.

91. Albuquerque RV, Malcher NS, Amado LL, Coleman MD, Dos Santos DC, Borges RS, et al. In vitro protective effect and antioxidant mechanism of resveratrol induced by dapsone hydroxylamine in human cells. PLoS One. 2015;10:e0134768.

92. Benitez DA, Pozo-Guisado E, Alvarez-Barrientos A, FernandezSalguero PM, Castellón EA. Mechanisms involved in resveratrolinduced apoptosis and cell cycle arrest in prostate cancer - derived cell lines. J Androl. 2007;28:282-93.

93. Wang H, Zhang H, Tang L, Chen H, Wu C, Zhao M, et al. Resveratrol inhibits TGF- $\beta 1$-induced epithelial-to-mesenchymal transition and suppresses lung cancer invasion and metastasis. Toxicology. 2013;303:139-46

94. Yin HT, Tian QZ, Guan L, Zhou Y, Huang XE, Zhang H. In vitro and in vivo evaluation of the antitumor efficiency of resveratrol against lung cancer. Asian Pacific J Cancer Prev. 2013;14:1703-6.

95. Rimando AM, Cuendet M, Desmarchelier C, Mehta RG, Pezzuto JM, Duke SO. Cancer chemopreventive and antioxidant activities of pterostilbene, a naturally occurring analogue of resveratrol. J Agric Food Chem. 2002;50:3453-7.

96. Schneider JG, Alosi JA, McDonald DE, McFadden DW. Pterostilbene inhibits lung Cancer through induction of apoptosis. J Surg Res. 2010;161:18-22.

97. Faridi Esfanjani A, Assadpour E, Jafari SM. Improving the bioavailability of phenolic compounds by loading them within lipidbased nanocarriers. Trends Food Sci Technol. 2018;76:56-66.

98. Nascimento-Souza MA, de Paiva PG, Pérez-Jiménez J, do Carmo Castro Franceschini S, Ribeiro AQ. Estimated dietary intake and major food sources of polyphenols in elderly of Viçosa, Brazil: a population-based study. Eur J Nutr. 2018;57:617-27.

99. On Chu K, Pang CC. Pharmacokinetics and Disposition of Green Tea Catechins Provisional chapter Pharmacokinetics and Disposition of Green Tea Catechins 2016; https://doi.org/10. 5772/intechopen.74190.

100. Pérez-Jiménez J, Fezeu L, Touvier M, Arnault N, Manach C, Hercberg S, et al. Dietary intake of 337 polyphenols in French adults. Am J Clin Nutr. 2011;93:1220-8.

101. Li Y, Yao J, Han C, Yang J, Chaudhry MT, Wang S, et al. Quercetin, inflammation and immunity. Nutrients. Multidisciplinary Digital Publishing Institute 2016;8:167.

102. Hollman PCH, Van Trijp JMP, Buysman MNCP, Martijn MS, Mengelers MJB, De Vries JHM, et al. Relative bioavailability of the antioxidant flavonoid quercetin from various foods in man. FEBS Lett. 1997;418:152-6.

103. Yang KY, Lin LC, Tseng TY, Wang SC, Tsai TH. Oral bioavailability of curcumin in rat and the herbal analysis from Curcuma longa by LC-MS/MS. J Chromatogr B Anal Technol Biomed Life Sci. 2007;853:183-9.

104. Villegas I, Sánchez-Fidalgo S. Alarcón de la Lastra C. new mechanisms and therapeutic potential of curcumin for colorectal cancer. Mol Nutr Food Res. 2008;52:1040-61.

105. Siviero A, Gallo E, Maggini V, Gori L, Mugelli A, Firenzuoli F, et al. Curcumin, a golden spice with a low bioavailability. J Herb Med. 2015;5:57-70.
106. Walle T, Hsieh F, Delegge MH, Oatis JE, Walle UK. High absorption but very low bioavailability of oral resveratrol in humans. Drug Metab Dispos. 2004;32:1377-82.

107. Soleas GJ, Yan J, Goldberg DM. Measurement of trans-resveratrol,(+)-catechin, and quercetin in rat and human blood and urine by gas chromatography with mass selective detection. Methods Enzymol. 2001;335:130-45.

108. Soleas G, Yan J, Goldberg D. Ultrasensitive assay for three polyphenols (catechin, quercetin and resveratrol) and their conjugates in biological fluids utilizing gas chromatography with mass selective detection. J Chromatogr B Biomed Sci Appl. 2001;757:161-72.

109. Almeida L, Vaz-da-Silva M, Falcão A, Soares E, Costa R, Loureiro AI, et al. Pharmacokinetic and safety profile of transresveratrol in a rising multiple-dose study in healthy volunteers. Mol Nutr Food Res. 2009;53:S7-15.

110. Loira-Pastoriza C, Todoroff J, Vanbever R. Delivery strategies for sustained drug release in the lungs. Adv Drug Deliv Rev. 2014;75: 81-91.

111. Velderrain-Rodríguez, GR, Palafox-Carlos H, Wall-Medrano A, Ayala-Zavala JF, Chen CO, Robles-S M, et al. Phenolic compounds: their journey after intake. 2014;5:189-97.

112. Teng H, Chen L. Polyphenols and bioavailability: an update. Crit Rev Food Sci Nutr. 2018:1-12. https://doi.org/10.1080/10408398. 2018.1437023.

113. Rasouli H, Farzaei MH, Khodarahmi R. Polyphenols and their benefits: a review. Int J Food Prop. 2017;20:S1700-41.

114. Vittorio O, Curcio M, Cojoc M, Goya GF, Hampel S, Iemma F, et al. Polyphenols delivery by polymeric materials: challenges in cancer treatment. Drug Deliv. 2017;24:162-80.

115. Kumari A, Yadav SK, Yadav SC. Biodegradable polymeric nanoparticles based drug delivery systems. Colloids Surf B: Biointerfaces. 2010;75:1-18.

116. Siddiqui IA, Adhami VM, Bharali DJ, Hafeez BB, Asim M, Khwaja SI, et al. Introducing Nanochemoprevention as a Novel Approach for Cancer Control: Proof of Principle with Green Tea Polyphenol Epigallocatechin-3-Gallate. 2009;69: 1712-1716.

117. Sanchez L, Yi Y, Yu Y. Effect of partial PEGylation on particle uptake by macrophages. Nanoscale. 2016;9:288-97.

118. Cheung RCF, Ng TB, Wong JH, Chan WY. Chitosan: an update on potential biomedical and pharmaceutical applications. Mar Drugs. 2015;13:5156-86.

119. Karthikeyan S, Hoti SL, Prasad NR. Resveratrol loaded gelatin nanoparticles synergistically inhibits cell cycle progression and constitutive NF-kappaB activation, and induces apoptosis in non-small cell lung cancer cells. Biomed Pharmacother. 2015;70: 274-82.

120. Hu CMJ, Aryal S, Zhang L. Nanoparticle-assisted combination therapies for effective cancer treatment. Ther Deliv. 2010;1:323-34.

121. Jensen DK, Jensen LB, Koocheki S, Bengtson L, Cun D, Nielsen HM, et al. Design of an inhalable dry powder formulation of DOTAP-modified PLGA nanoparticles loaded with siRNA. J Control Release. 2012;157:141-8.

122. Tahara K, Sakai T, Yamamoto H, Takeuchi H, Hirashima N, Kawashima Y. Improved cellular uptake of chitosan-modified PLGA nanospheres by A549 cells. Int J Pharm. 2009;382:198 204.

123. Khalil NM, Nascimento TCF do, Casa DM, Dalmolin LF, Mattos AC de, Hoss I, et al. Pharmacokinetics of curcumin-loaded PLGA and PLGA-PEG blend nanoparticles after oral administration in rats. Colloids Surfaces B Biointerfaces 2013;101:353-360.

124. Teong B, Lin CY, Chang SJ, Niu GCC, Yao CH, Chen IF, et al. Enhanced anti-cancer activity by curcumin-loaded hydrogel nanoparticle derived aggregates on A549 lung adenocarcinoma cells. J Mater Sci Mater Med. 2015;26:49. 
125. Tsai YM, Chien CF, Lin LC, Tsai TH. Curcumin and its nanoformulation: the kinetics of tissue distribution and blood-brain barrier penetration. Int J Pharm. 2011;416:331-8.

126. Kumar SP, Birundha K, Kaveri K, Devi KTR. Antioxidant studies of chitosan nanoparticles containing naringenin and their cytotoxicity effects in lung cancer cells. Int J Biol Macromol. 2015;78:8795.

127. Karthikeyan S, Rajendra Prasad N, Ganamani A, Balamurugan E. Anticancer activity of resveratrol-loaded gelatin nanoparticles on NCI-H460 non-small cell lung cancer cells. Biomed Prev Nutr. 2013;3:64-73.

128. Singh M, Bhatnagar P, Mishra S, Kumar P, Shukla Y, Gupta KC. PLGA-encapsulated tea polyphenols enhance the chemotherapeutic efficacy of cisplatin against human cancer cells and mice bearing Ehrlich ascites carcinoma. Int J Nanomedicine. 2015;10: 6789-809.

129. Duan J, Mansour HM, Zhang Y, Deng X, Chen Y, Wang J, et al. Reversion of multidrug resistance by co-encapsulation of doxorubicin and curcumin in chitosan/poly(butyl cyanoacrylate) nanoparticles. Int J Pharm. 2012;426:193-201.

130. Sadzuka Y, Nagamine M, Toyooka T, Ibuki Y, Sonobe T. Beneficial effects of curcumin on antitumor activity and adverse reactions of doxorubicin. Int J Pharm. 2012;432:42-9.

131. Popov A, Schopf L, Bourassa J, Chen H. Enhanced pulmonary delivery of fluticasone propionate in rodents by mucus-penetrating nanoparticles. Int J Pharm. 2016;502:188-97.

132. Lee C, Choi JS, Kim I, Oh KT, Lee ES, Park ES, et al. Long-acting inhalable chitosan-coated poly(lactic-co-glycolic acid) nanoparticles containing hydrophobically modified exendin- 4 for treating type 2 diabetes. Int J Nanomedicine. 2013;8:2975-83.

133. Zhang T, Chen Y, Ge Y, Hu Y, Li M, Jin Y. Inhalation treatment of primary lung cancer using liposomal curcumin dry powder inhalers. Acta Pharm Sin B. 2018;8:440-8.

134. Thorley AJ, Tetley TD. New perspectives in nanomedicine. Pharmacol Ther. 2013;140:176-85.

135. Mahmud A, Discher DE. Lung vascular targeting through inhalation delivery: insight from filamentous viruses and other shapes. IUBMB Life. 2011;63:607-12.

136. Sung JC, Pulliam BL, Edwards DA. Nanoparticles for drug delivery to the lungs. Trends Biotechnol. 2007;25:563-70.

137. Alexiou C, Arnold W, Klein RJ, Parak FG, Hulin P, Bergemann C, et al. Locoregional cancer treatment with magnetic drug targeting. Cancer Res. 2000;60:6641-8.

138. Pilcer G, Amighi K. Formulation strategy and use of excipients in pulmonary drug delivery. Int J Pharm. 2010;392:1-19.

139. El-Sherbiny IM, Smyth HDC. Controlled release pulmonary administration of curcumin using swellable biocompatible microparticles. Mol Pharm. 2012;9:269-80.

140. Ungaro F, d'Angelo I, Coletta C, d'Emmanuele di Villa Bianca R, Sorrentino R, Perfetto B, et al. Dry powders based on PLGA nanoparticles for pulmonary delivery of antibiotics: modulation of encapsulation efficiency, release rate and lung deposition pattern by hydrophilic polymers. J Control Release. 2012;157:149 59.

141. Patton JS, Byron PR. Inhaling medicines: delivering drugs to the body through the lungs. Nat Rev Drug Discov. 2007;6:67-74.

142. Azarmi S, Roa WH, Löbenberg R. Targeted delivery of nanoparticles for the treatment of lung diseases. Adv Drug Deliv Rev. 2008;60:863-75.

143. Mansour HM, Rhee Y-S, Wu X. Nanomedicine in pulmonary delivery. Int J Nanomedicine. 2009;4:299-319.

144. Yamamoto H, Kuno Y, Sugimoto S, Takeuchi H, Kawashima Y. Surface-modified PLGA nanosphere with chitosan improved pulmonary delivery of calcitonin by mucoadhesion and opening of the intercellular tight junctions. J Control Release. 2005;102:37381.

145. Nieto-Orellana A, Coghlan D, Rothery M, Falcone FH, Bosquillon C, Childerhouse N, et al. Dry-powder formulations of non-covalent protein complexes with linear or miktoarm copolymers for pulmonary delivery. Int $\mathrm{J}$ Pharm. 2018;540:78-88.

146. Gaul R, Ramsey JM, Heise A, Cryan SA, Greene CM. Nanotechnology approaches to pulmonary drug delivery: targeted delivery of small molecule and gene-based therapeutics to the lung. In: Grumezescu AM, editor. Design of nanostructures for versatile therapeutic applications. Norwich: William Andrew; 2018. p. 221-53.

147. Menon JU, Ravikumar P, Pise A, Gyawali D, Hsia CCW, Nguyen KT. Polymeric nanoparticles for pulmonary protein and DNA delivery. Acta Biomater. 2014;10:2643-52.

148. Rodrigues TC, Oliveira MLS, Soares-Schanoski A, Chavez-Rico SL, Figueiredo DB, Gonçalves VM, et al. Mucosal immunization with PspA (pneumococcal surface protein a)-adsorbed nanoparticles targeting the lungs for protection against pneumococcal infection. PLoS One. 2018;13:e0191692.

149. Liu XB, Ye JX, Quan LH, Liu CY, Deng XL, Yang M, et al. Pulmonary delivery of scutellarin solution and mucoadhesive particles in rats. Eur J Pharm Biopharm. 2008;70:845-52.

150. Liu K, Chen W, Yang T, Wen B, Ding D, Keidar M, et al. Paclitaxel and quercetin nanoparticles co-loaded in microspheres to prolong retention time for pulmonary drug delivery. Int $\mathrm{J}$ Nanomedicine. 2017;12:8239-55.

Publisher's note Springer Nature remains neutral with regard to jurisdictional claims in published maps and institutional affiliations. 